Article

\title{
Integration of Measurements and Time Diaries as Complementary Measures to Improve Resolution of BES
}

\author{
Jakob Carlander ${ }^{1, *}$, Kristina Trygg ${ }^{2}(\mathbb{D})$ and Bahram Moshfegh ${ }^{1,3}$ \\ 1 Division of Building, Energy and Environment Technology, Department of Technology and Environment, \\ University of Gävle, 80176 Gävle, Sweden; bahram.moshfegh@liu.se \\ 2 Technology and Social Change, Linköping University, 58183 Linköping, Sweden; kristina.trygg@liu.se \\ 3 Division of Energy Systems, Department of Management and Engineering, Linköping University, \\ 58183 Linköping, Sweden \\ * Correspondence: Jakob.Carlander@hig.se
}

Received: 23 April 2019; Accepted: 27 May 2019; Published: 30 May 2019

\begin{abstract}
Building energy simulation (BES) models rely on a variety of different input data, and the more accurate the input data are, the more accurate the model will be in predicting energy use. The objective of this paper is to show a method for obtaining higher accuracy in building energy simulations of existing buildings by combining time diaries with data from logged measurements, and also to show that more variety is needed in template values of user input data in different kinds of buildings. The case studied in this article is a retirement home in Linköping, Sweden. Results from time diaries and interviews were combined with logged measurements of electricity, temperature, and $\mathrm{CO}_{2}$ levels to create detailed occupant behavior schedules for use in BES models. Two BES models were compared, one with highly detailed schedules of occupancy, electricity use, and airing, and one using standardized input data of occupant behavior. The largest differences between the models could be seen in energy losses due to airing and in household electricity use, where the one with standardized user input data had a higher amount of electricity use and less losses due to airing of $39 \%$ and $99 \%$, respectively. Time diaries and interviews, together with logged measurements, can be great tools to detect behavior that affects energy use in buildings. They can also be used to create detailed schedules and behavioral models, and to help develop standardized user input data for more types of buildings. This will help improve the accuracy of BES models so the energy efficiency gap can be reduced.
\end{abstract}

Keywords: building energy simulation; occupant behavior; energy performance; indoor climate; retirement home; user input data

\section{Introduction}

In the European Union (EU), buildings are responsible for approximately $40 \%$ of energy use and 36\% of $\mathrm{CO}_{2}$ emissions [1]. The building sector is also responsible for about $60 \%$ of electricity consumption, and about one-third of the total energy use in the building sector can be related to non-domestic buildings [2]. In 2016, the total energy use in the building sector in Sweden was 80.5 TWh, and approximately $27 \%$ of this energy use was from public buildings [3]. When renovating or constructing new buildings, it is important to have an idea on how the energy use will be affected by the users. One way to do this is with building energy simulation (BES). However, BES models rely on a variety of different input data, and the more accurate the input data are, the more accurate the model will be in predicting energy use. In many cases, when it comes to whole-building simulation, there are significant discrepancies between simulated results and actual energy use of the real buildings [4]; this is called the 
"energy performance gap" [5]. However, whole-building simulation is often held as the best approach when it comes to analyzing performance in the building industry [6]. Many times, these differences come from the behavioral patterns of the residents, which are hard to predict and to simulate [7]. In Sweden, it is now standard to use template values and schedules for user behavior. The template values used in Sweden are usually from Sveby's reports on standardized user input data, which are available for residential housing, office buildings, and schools [8-10]. Sveby stands for "standardize and verify energy performance in buildings", and it is a branch overlapping program that produces instruments that aid and standardize energy use. However, these template values and schedules were only developed for residential buildings in the form of apartment buildings and detached homes, and not for other types of residential buildings such as retirement homes or homes for people with special needs. In Reference [11], the authors made a review article where they studied research articles which dealt with the impact of occupant behaviors on building energy analysis. They concluded that most research in the field studied residential and office buildings, while a small number studied commercial and educational buildings, and sparse attention was given to recreational and healthcare facilities. As this paper shows, the available template values from Sveby do not always provide a good prediction of user behavior and, therefore, the simulations lack in accuracy compared to real buildings.

Another way to simulate user behavior and its impact on energy use in a building is to use behavioral models. Many behavioral models that has been developed uses data from large national surveys based on time diaries [12-15]. However, these behavioral models were also only developed for residential housing. In Reference [12], the authors presented a method for generating realistic occupancy schedules and electricity load profiles for United Kingdom (UK) households, where they used data from a large time-use survey (TUS) on how people used their time, which was conducted in the UK in 2000. The data used included location of participants and if they were active (not asleep) for each ten-minute diary period. The data did not contain any information on electricity use; however, according to the article, electricity use is highly connected to active occupants. Their conclusions were that the simulated output and original TUS data correlate very closely, and that the technique of building transaction matrices from such data in order to generate synthetic data series is very effective and computationally efficient. The authors of Reference [13] presented a method to generate load profiles for household electricity and domestic hot-water (DHW) use from time-use data. The profiles were generated from a detailed dataset on the time use for everyday activities in Swedish households, and the results were compared to electricity and hot-water profiles from recently performed measurements. They said that their model makes realistic reproductions of electricity demand for individual households and generates well-corresponding load distributions when compared to available measurement data. "The overall energy-use pattern found in measured data is well described by the model, while magnitudes sometimes deviate" [13]. In Reference [14], the authors developed a high-spatial-resolution model of energy use in residential buildings using data from national TUS data from the United States (US) residential sector. Their model was more detailed then previous models in the way that it was used down to a zone level in a building rather than an entire building. One conclusion they drew is that, if energy simulation tools can result in better decisions in energy-efficient renovations of single-unit structures where owners have full control over their property (in the US, this is approximately 65 million properties), it can have substantial societal impact. In Reference [15], the authors also made a probabilistic occupancy model for residential buildings, and tested it against Belgian TUS data. However, none of these studies or behavioral models were made for specific types of buildings; rather, they were made from large datasets and only from regular residential buildings. To the best knowledge of the authors of this article, such behavioral models are not widely used compared to the use of template values in the building industry.

The aim of this article is to show a method on how to improve the resolution of BES models on existing buildings by integrating measurements of electricity use, indoor temperature, and $\mathrm{CO}_{2}$ levels with time diaries. The aim is also to show how occupant behavior in a retirement home can differ from occupant behavior according to template values for regular residential buildings, and how these differences can affect energy use in a building. It shows the need for the development of template 
values to use in BES models for more types of buildings than currently available. The article will also contribute to the knowledge on occupant behavior in retirement homes, which according to Reference [11] is sparse.

\section{Method and Case Description}

In the present study, a model of an existing building was created in the general simulation software IDA-ICE (IDA Indoor Climate and Energy) version 4.8 [16]. Input data for the model were obtained through interviews and time diaries, logged measurements, blueprints, and onsite observations. IDA-ICE is a dynamic whole-building energy simulation software that was released in 1998, in which building energy use, indoor climate, and heating and cooling loads can be simulated. The validity of IDA-ICE was tested several times throughout the years with good results [16-18].

\subsection{Theory and Related Research}

\subsubsection{Validation of BES Models}

There are three basic approaches for validating BES models. The first one is analytical validation, where the model is compared to a given and exact solution, the second approach is peer model validation, where the model is compared to peer models with the same input data, and the third approach is empirical/realistic validation, where the model is compared to empirically collected data $[19,20]$. When performing a realistic validation, one can use metering and auditing data from actual residential and commercial buildings to compare the model [19]. User behavior is usually also included in these models, but setting occupant behavior schedules is difficult due to the variable nature of occupants [19]. In their conclusion, Sanquist and Ryan [19] stated that realistic validation cases need to be included in building energy validation procedures to improve the accuracy of building energy models. Sanquist and Ryan [19] also stated that there were not any major improvements in the methods used to model occupant behavior, and that the use of stochastic and other detailed behavior models could improve predictions of energy models, but at a much greater cost than current schedule-based occupant models. There were not many attempts at empirical validation of occupied buildings [21]. A few examples on studies that used empirical validation include References [21-24]. La Fleur, Moshfegh, and Rohdin [21] measured electricity, indoor temperature, and $\mathrm{CO}_{2}$ level in two apartments, both before and after renovation. The aim of their study was to present numerical predictions, validation, and evaluation of energy use and indoor climate for the building before and after renovation. Good agreement was reported, both in annual heat demand and indoor temperature, between simulation results and measurements. La Fleur, Moshfegh, and Rohdin [21] concluded that assumptions on user behavior have significant impact on energy-saving potential. In the article by Liu et al. [22], two almost identical buildings built in the 1970s in Sweden were studied. One building was retrofitted during 2009-2010, and the other was not yet retrofitted. In the study, a mixed-methods approach was used, i.e., conducted measurements and simulations on the buildings, as well as handing out questionnaires with questions about the indoor environment to the residents of both buildings. The electricity use and indoor temperature were measured. Based on the electricity measurements, schedules for electricity use were created and compared with the predicted results of indoor temperature and heat demand; good agreement was achieved between them. A similar approach was conducted by Reference [23], as they validated their BES model against detailed measurements of electricity at the appliance level in a passive house, with good agreement. Some of the differences in simulated and real results in building simulation models can, as previously stated by Reference [21] amongst others, be due to behavior of the building's occupants. Large offsets between simulated results and actual energy use, due to differences between actual and simulated behavior, can be a problem [7]. Gauthier and Shipworth [25] described a couple of different behavioral responses connected with thermal discomfort according to the following factors: increasing/decreasing clothing insulation level (clo), operative temperature, and increasing frequency, duration, and/or amplitude of localized behavioral responses 
such as consuming hot food and/or liquids, changing location to another room in the dwelling, opening and closing of curtains and/or windows, and changing body position. Some of these responses have a direct impact on energy use in the dwelling, such as opening and closing of windows [26]. A lot of behavior models were designed for use in energy simulations, and many of them use data from national time-use surveys, which are based on data from time diaries [12-15], as described above. These models rarely took opening of windows and doors into account; however, other models were developed for this purpose (e.g., Reference [26]). A method on how to model and validate BES models was proposed by Raftery et al. [4]. The proposed approach was evidence-based, which means that changes to the input parameters could only be made according to available evidence under clearly defined priorities. This was done to minimize the differences between real and simulated energy use for buildings [4]. The proposed method follows a certain sequence of steps that should be done in order to get as good results as possible. The first step is preparation, where an initial model is constructed, and historical weather data and calibration data are gathered, in addition to setting acceptance criteria for the model. Calibration data should be gathered and used according to the following hierarchy: (1) data-logged measurement; (2) spot or short-term measurement; (3) direct observation; (4) operator and personnel interviews; (5) operation documents; (6) commissioning documents; (7) benchmark studies and best practice guides; (8) standards, specifications, and guidelines; (9) design stage information. The acceptance criteria are values of, for instance, energy use and zonal indoor temperatures during a certain period of time, whereby the model should match to be called validated. In the second step, the model is updated with the information gathered, and the simulation is run. The model is tested against the acceptance criteria, and, if it checks out, the model is validated. If it does not meet the acceptance criteria, an iterative process is started where new measurements or data are obtained, and the model is updated and tested until it meets the acceptance criteria. According to Reference [4], the proposed methodology was based on some of the best techniques from the reviewed literature of their study, and it combined these with an evidence-based approach that used version control software to track the calibration process.

Standards, specifications, guidelines, and template values, such as Sveby's standardized user input data, come in at place eight out of nine in the hierarchy proposed by Reference [4] for input data in building energy simulations. Despite this, standards such as user input data for housing, office buildings, and schools from Sveby are consistently used when new building energy performance is simulated in the design phase of a project. They are also used when renovations and/or retrofits are done in existing buildings. This is mainly because more accuracy is not required by the Swedish Boverket (National Board of Housing, Building, and Planning).

\subsubsection{Time Diaries and Interviews}

Time diaries are a method developed from the time-geographical perspective, and are commonly used in everyday life studies on energy use with a time-geographical approach (e.g., References [27-29]). With this method, it is possible to describe and analyze the relationship between activity, location, and movements of individuals. On the individual level, a rhythmic pattern may occur, which shows the central role of the dwelling, the workplace, and, for shorter visits, the places where friends and relatives live and where shops are located. It is also of interest to understand how often or for how long a social activity occurs, and how these social activities relate to other events that are involved in structuring an individual's daily, weekly, or monthly pattern (e.g., how a coffee break with a friend in the apartment affects energy use). The difference between a time diary and an ordinary diary is that it is a written biography that describes a period of an individual's life more or less systematically. Even though the time diary often has a certain aim related to the study objectives, and the researchers specify what they want the respondent to reflect upon, in the end, it is the respondent who decides what will be written and what will be left out [30]. Asking people to write diaries will make people more aware of the practices they are involved in (e.g., how many times they open the window (routines)). A time diary offers a chance to reflect upon their everyday life, which might get them to remember 
things and why they are doing things in a specific way. This can also help the respondents explain why they do certain things. Today, a time diary might be in paper or digital format. In a digital format time diary, people record their activities on their mobile phone or computer and then share those electronically [31]. This is less time-consuming for both the respondent and the researcher.

\subsubsection{Energy Affecting Behavior in Swedish Households}

According to Reference [10], the general population in Sweden has the following routines and behavior which affect energy: they are at home for about $14 \mathrm{~h}$ per day and use annually around $30 \mathrm{kWh} / \mathrm{m}^{2}$ of household electricity, with about $4 \mathrm{kWh} / \mathrm{m}^{2}$ of energy losses due to airing and $25 \mathrm{kWh} / \mathrm{m}^{2}$ due to DHW use.

\subsection{The Case Study}

Comparable with many countries around the world, the population of Sweden is aging [32,33]. The city block consists of tenants with different types of rental forms and, in the building, both housing and care homes (dementia housing) and service dwellings are present. Some tenants rent directly from the private property owner, while other tenants rent through the municipality (service and dementia housing and special housing). Most people who live in the housing complex are age 65 or older. Older people in Sweden are more reluctant to change housing than younger age groups [34,35]. In Sweden, aging in place was a political goal for a long time; hence, most older people in Sweden live in their ordinary homes with the assistance of home and medical care when needed. How many people live in assisted-living accommodation and how many have assistance in home can be seen in Table 1 .

Table 1. Number of people with assistance in their own home and number of people living in assisted-living accomodation in Sweden (men and women; 2016) [32].

\begin{tabular}{ccc}
\hline Age & People with Assistance in Home & $\begin{array}{c}\text { People in Assisted-Living } \\
\text { Accommodation }\end{array}$ \\
\hline $65+$ & 228,654 & 106,002 \\
$65-79$ & 68,536 & 84,843 \\
$80+$ & 160,118 & 21,159 \\
\hline
\end{tabular}

The city block that was the case for this study contains 99 apartments, of which 35 are assisted-living accommodation for elderly people. Elderly people have their own apartments with a safety alarm, and two healthcare providers (private and public) operate in the building, as well as a nurse. The building complex consist of five different buildings, where it is possible to walk between three of them without having to go outside (they are in the same building body); the other two buildings are detached three-story buildings with 15 apartments in each, evenly distributed on the three stories. No renovation was done since the block was built in 1983, with only minor repairs taking place. This type of housing includes a canteen where lunch is served, and there are also leisure activities in which all elderly people in the municipality can take part. Most of the people living in the block are at least 65 years old. Tenants in this specific building complex rent an apartment directly from the property owner, and the people in need of assisted living rent their apartment from the municipality. There is also a residence for elderly people with dementia in a separate part of the building complex. The building that was modeled and simulated was one of the two detached buildings. The building and the simulation model can be seen in Figure 1. Technical data of the modeled building, as well as data of its location, can be found in Table 2. This specific city block is geographically located in Östergötland, a county in the south of Sweden that has a continental climate and belongs to the northern part of the temperate zone. 
Table 2. Technical data of the modeled building.

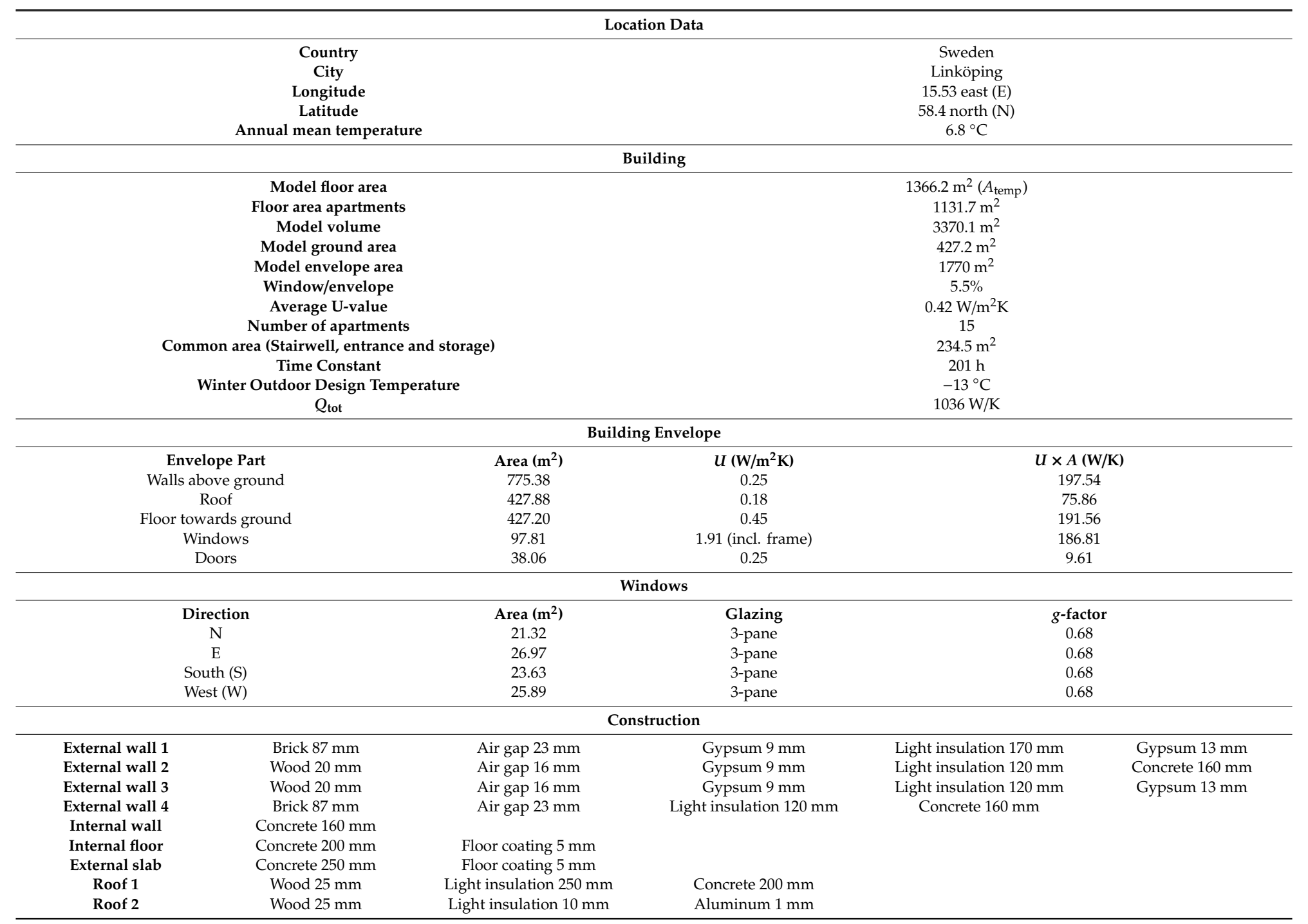




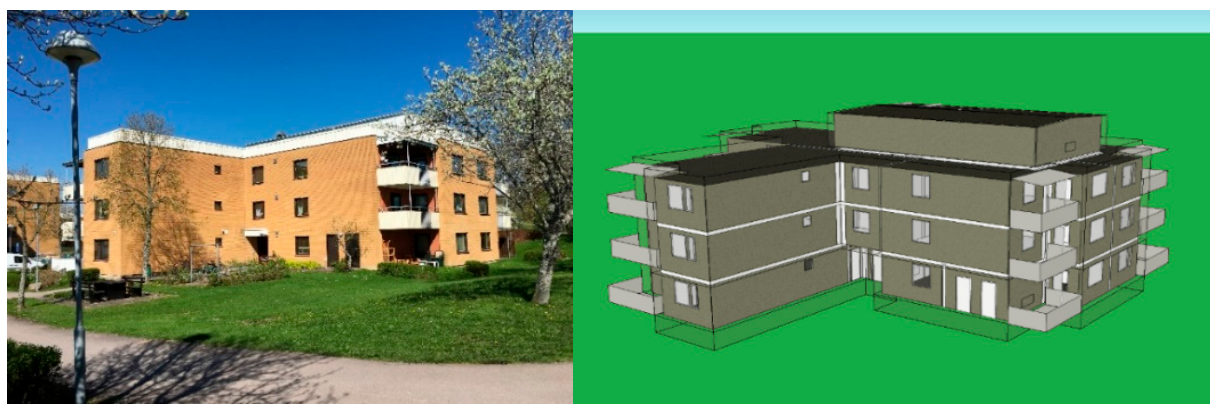

(a)

(b)

Figure 1. (a) Building that was modeled. (b) Model of the building in IDA-ICE (IDA Indoor Climate and Energy).

\subsection{Data Collection}

The data for this study were obtained through interviews and time diaries, logged measurements, blueprints, and onsite observations. The data were largely collected between 2014 and 2016, based on a pilot study carried out in 2013.

\subsubsection{Conducting Time Diaries and Interviews}

All tenants received an invitation to participate in the study (except those in the residence for dementia) by participating in interviews and/or by writing time diaries for a week. The interviews each lasted for at least one hour. Interviews were used to understand social phenomena and to complement the time diaries. For the interviews and time diaries, a total of 16 tenants agreed to participate. Ultimately, 11 of them participated in both the interviews and the time diaries. The tenants that agreed to participate kept a time diary for one week in which they wrote time, activity, place, with whom, which electrical appliances were used, and other comments. Two of the subjects lived with their spouse and also wrote their spouse's activities in the time diary. Table 3 presents general information on the subjects that participated in both time diaries and interviews.

Table 3. Gender, age, civil status, and working status of the occupants in the present study.

\begin{tabular}{cc}
\hline Description & Facts \\
\hline Gender & Female (8), Male (5) \\
Age & $58-94$ (mean 85, median 78) \\
Civil status & Single (9), married (4: two couples) \\
Retired/working & $11 / 2$ \\
\hline
\end{tabular}

\subsubsection{Field Measurements}

At the same time as the tenants wrote time diaries, measurements of $\mathrm{CO}_{2}$ levels, relative humidity, indoor temperature, and electricity use were logged in their apartment. Temperature was measured with three loggers, one in the kitchen, one in the living room, and one in the bedroom. In some apartments, there were more than one bedroom, as a result, the temperature logger was set up in the master bedroom or the one that was used as bedroom. Relative humidity was logged in the kitchen and $\mathrm{CO}_{2}$ levels were logged either in the living room or the hallway. Electricity use was logged with an EliQ optical eye at five-minute intervals for each apartment. The logged measurements and time diaries were done between the period of 17 November and 2 February, two apartments at a time. Logged measurements were done in 12 of the 15 apartments in the building, and 11 of these tenants also kept a time diary; the tenants in the three remaining apartments did not wish to participate in the study. An energy mapping was also performed for the city block to allocate the different uses of electricity, energy for heating of domestic hot water (DHW), and energy for space 
heating. Some data could only be obtained for the entire block, such as energy for space heating and DHW use. Electricity meters of 15 apartments were, therefore, read once a week for two months, with approval from the tenants. The same was done with the electricity meters measuring the facility electricity, which includes electricity for the lighting of stairwells, corridors, common areas, and outside lighting, electricity for operation of automatic doors, elevators, and laundry rooms, and electricity used for a central ventilation system in the common area and offices of the block. Apart from the energy mapping, the tightness of the building envelope was measured by using the blower door technique in one apartment. Readings, measurements, and used measurement equipment can be found in Table 4, and each measuring equipment's accuracy can be found in Table 5. On-site observations were made throughout the building complex, as it was useful in terms of understanding how the building was used by the tenants and the people working there, as well as also to check that the construction matched the provided blueprints of the building. Photographs were also taken to enrich the data material (see Reference [30]). Which data were used and for what purpose can be seen in Table 6.

Table 4. Measurements at the city block and the modeled building, time resolution, and time span, as well as which measurement equipment was used.

\begin{tabular}{|c|c|c|c|c|}
\hline Measuring Type & Measuring Equipment & Area & Time Resolution & Timespan \\
\hline District heating & $\begin{array}{l}\text { Meter at the city block's } \\
\text { heating central }\end{array}$ & $\begin{array}{l}\text { Entire city block (one } \\
\text { measuring point) }\end{array}$ & weekly & 2 months \\
\hline $\begin{array}{c}\text { Domestic } \\
\text { hot-water use and } \\
\text { temperature }\end{array}$ & $\begin{array}{l}\text { Meter at the city block's } \\
\text { heating central }\end{array}$ & $\begin{array}{l}\text { Entire city block (one } \\
\text { measuring point) }\end{array}$ & weekly & 2 months \\
\hline $\begin{array}{c}\text { Domestic } \\
\text { cold-water use }\end{array}$ & $\begin{array}{l}\text { Meter at the city block's } \\
\text { heating central }\end{array}$ & $\begin{array}{l}\text { Entire city block (one } \\
\text { measuring point) }\end{array}$ & weekly & 2 months \\
\hline Facility electricity & Electricity meter & $\begin{array}{l}\text { Entire city block (six } \\
\text { measuring points) }\end{array}$ & weekly & 2 months \\
\hline $\begin{array}{l}\text { Apartment } \\
\text { electricity }\end{array}$ & Electricity meter & $\begin{array}{c}\text { Ekholmsvägen } 106 \text { (15 } \\
\text { apartments) }\end{array}$ & weekly & 2 months \\
\hline Total electricity & Eliq & $\begin{array}{l}\text { Entire city block (incoming } \\
\text { electricity for each facility } \\
\text { and for the central } \\
\text { ventilation; } 5 \text { measuring } \\
\text { points in total) }\end{array}$ & Every 5 minutes & 1 week \\
\hline $\begin{array}{l}\text { Momentary total } \\
\text { electricity }\end{array}$ & $\begin{array}{l}\text { Fluke 41B Power } \\
\text { harmonics analyzer + } \\
\text { Universal Technic } \\
\text { current clamps }\end{array}$ & $\begin{array}{l}\text { Entire city block (incoming } \\
\text { electricity for each facility } \\
\text { and for the central } \\
\text { ventilation; } 5 \text { measuring } \\
\text { points in total) }\end{array}$ & - & - \\
\hline $\begin{array}{l}\text { Momentary } \\
\text { temperature }\end{array}$ & Swema3000 & $\begin{array}{c}\text { Stairwells, ventilation } \\
\text { outtakes }\end{array}$ & - & - \\
\hline $\begin{array}{l}\text { Logged } \\
\text { temperature }\end{array}$ & Tinytag Plus2 & 12 apartments & Every 5 minutes & 1 week \\
\hline $\begin{array}{l}\text { Logged apartment } \\
\text { electricity }\end{array}$ & Eliq & 12 apartments & Every 5 minutes & 1 week \\
\hline Relative humidity & $\begin{array}{c}\text { Tinytag View2 Temp and } \\
\text { RH logger }\end{array}$ & 12 apartments & Every 5 minutes & 1 week \\
\hline $\mathrm{CO}_{2}$ & Tinytag $\mathrm{CO}_{2}$ & Dining hall +12 apartments & Every 5 minutes & 1 week \\
\hline $\begin{array}{c}\text { Energy use from } \\
\text { apartment } \\
\text { ventilation } \\
\end{array}$ & $\begin{array}{l}\text { Everflourish power } \\
\text { meter EMT707CTL }\end{array}$ & $\begin{array}{l}\text { Ventilation unit in one } \\
\text { apartment }\end{array}$ & 1 week & 1 week \\
\hline $\begin{array}{c}\text { Momentary } \\
\text { ventilation flows }\end{array}$ & Swema3000 & $\begin{array}{l}\text { Outlets on roof }+ \text { measured } \\
\text { on central ventilation system }\end{array}$ & - & - \\
\hline $\begin{array}{l}\text { Building envelope } \\
\text { tightness }\end{array}$ & $\begin{array}{c}\text { Retrotec DM32 Blower } \\
\text { door }\end{array}$ & 1 apartment & - & - \\
\hline
\end{tabular}


Table 5. Accuracy and area of use for measuring equipment used in the study. N/A—not applicable.

\begin{tabular}{|c|c|c|c|}
\hline Equipment & Measures & Equipment Accuracy & Manufacturer \\
\hline EliQ optical eye & Household electricity use & N/A & $\begin{array}{l}\text { Eliq, Gothenburg, } \\
\text { Sweden }\end{array}$ \\
\hline $\begin{array}{l}\text { Fluke 41B Power } \\
\text { harmonics analyser }\end{array}$ & Facility electricity & $\begin{array}{c} \pm 1 \% \text { for active watts (VA) } \\
\quad+\text { probe specs }\end{array}$ & Fluke, Everett, WA, USA \\
\hline $\begin{array}{l}\text { Universal Technic } \\
\text { current clamps }\end{array}$ & Facility electricity & N/A & $\begin{array}{c}\text { Universal Technic, Paris, } \\
\text { France }\end{array}$ \\
\hline Swema3000 & $\begin{array}{l}\text { Temperature and air } \\
\text { speed }\end{array}$ & $\pm 0.1^{\circ} \mathrm{C}, \pm 0.03 \mathrm{~m} / \mathrm{s}$ & $\begin{array}{l}\text { Swema, Stockholm, } \\
\text { Sweden }\end{array}$ \\
\hline Tinytag Plus2 & Temperature & $\pm 0.35^{\circ} \mathrm{C}$ & $\begin{array}{c}\text { Intab, Stenkullen, } \\
\text { Sweden }\end{array}$ \\
\hline Tinytag View2 & $\begin{array}{l}\text { Temperature and relative } \\
\text { humidity (RH) }\end{array}$ & $\pm 0.4^{\circ} \mathrm{C}, \mathrm{RH} \pm 3 \%$ & $\begin{array}{l}\text { Intab, Stenkullen, } \\
\text { Sweden }\end{array}$ \\
\hline Tinytag $\mathrm{CO}_{2}$ logger & $\begin{array}{l}\text { Concentration of carbon } \\
\text { dioxide in air }\end{array}$ & $\pm 3 \%$ & $\begin{array}{c}\text { Intab, Stenkullen, } \\
\text { Sweden }\end{array}$ \\
\hline $\begin{array}{l}\text { Everflourish power } \\
\text { meter EMT707CTL }\end{array}$ & Household electricity & N/A & $\begin{array}{c}\text { Everflourish, } \\
\text { Friedrichsthal, Germany }\end{array}$ \\
\hline $\begin{array}{c}\text { Retrotec Blower Door } \\
3100 \text { with DM2 digital } \\
\text { pressure gauge }\end{array}$ & $\begin{array}{l}\text { Building envelope } \\
\text { airtightness }\end{array}$ & $\begin{array}{l} \pm 5 \% \text { flow rate accuracy, } \\
\pm 1 \% \text { pressure reading } \\
\text { accuracy (or } \pm 0.15 \mathrm{~Pa} \text { ) }\end{array}$ & $\begin{array}{c}\text { Retrotec, Everson, WA, } \\
\text { USA }\end{array}$ \\
\hline
\end{tabular}

Table 6. Part of the process in which the gathered data were used. BES-building energy simulation.

\begin{tabular}{|c|c|c|c|}
\hline Step in Process & Construction of Model & $\begin{array}{l}\text { Creating Detailed } \\
\text { User Schedules }\end{array}$ & Validating BES Model \\
\hline Used data & $\begin{array}{l}\text { Blueprints of the building and } \\
\text { on-site observation of } \\
\text { construction, measured } \\
\text { ventilation airflows, } \\
\text { temperature, number of } \\
\text { occupants in each apartment, } \\
\text { and measurements of building } \\
\text { envelope tightness. }\end{array}$ & $\begin{array}{c}\text { Time diaries, } \\
\text { interviews, and } \\
\text { household electricity } \\
\text { use }\end{array}$ & $\begin{array}{l}\text { Logged measurements of } \\
\mathrm{CO}_{2} \text { levels, indoor } \\
\text { temperature, and } \\
\text { household electricity use }\end{array}$ \\
\hline
\end{tabular}

\subsection{Modeling and Validation of BES Models for This Study}

Two models of the same building were created in this study: one reference model, BES-ref (building energy simulation reference model), which used template values for occupancy, airing, and electricity use, and one model where detailed schedules for occupancy, airing, and electricity were used, BES-v.2 (building energy simulation model version 2). The modeling of both BES-ref and BES v.2 was inspired by the method developed by Reference [4]. An initial model was built according to blueprints made available from the housing company, and the construction in the blueprints was confirmed with on-site observations where possible.

\subsubsection{Model Input Data and Creation of Detailed Schedules}

Input data for BES-ref and BES-v.2 can be seen in Table 7. Input data in the form of schedules for occupancy (absent from 7:00 a.m. to 5:00 p.m.) and electricity use (electricity use between 6:00 and 8:00 a.m. and between 3:00 and 11:00 p.m.) in BES-ref were set according to Sveby's [10] user input data, and losses due to airing were added after simulations according to Sveby's [10] user input data. For both BES-ref and BES-v.2, temperature was set according to logged measurements from 12 apartments, while ventilation air flows were set according to measurements at the inlets and outlets, DHW use was set according to the mean use per square meter for the city block, the heat exchanger 
efficiency was approximated for each apartment by analyzing the electricity use of the air handling unit (AHU), and the building airtightness was set according to measurements with the blower door technique. For BES-v.2, input data in the form of schedules for occupancy, electricity use, and airing were created by combining information from time diaries and interviews, with logged measurements of electricity use, indoor temperature, and $\mathrm{CO}_{2}$ levels. In cases where there were multiple people living in an apartment, several occupants were used in the simulations, each with their own unique occupancy schedule. An example on how the detailed schedules were created is presented below. The example follows the creation of detailed schedules for one day and one apartment. The first thing one needs to do is analyze the logged measurements and check the time diaries for reasons on why drops and peaks occur in temperature, $\mathrm{CO}_{2}$ levels, and electricity use. In Figure 2, we can see the logged measurements from apartment 5 on the second floor for 19 November, and Table 8 shows a transcription of the time diary from the same day written by the tenant living in that specific apartment.

The first interesting thing in the measurements for $\mathrm{CO}_{2}$ levels and temperature occurred around 8:30 a.m., as can be seen in Figure 2. To see the reason for the drop in $\mathrm{CO}_{2}$ and temperature, we can look at the entries from the time diary in Table 8 . The tenant wrote that she put out linen on the balcony and left the balcony door open from 8:30-8:50 a.m. This is the most probable cause for the drop in both temperature and $\mathrm{CO}_{2}$ level. To represent this in the model, an opening of the balcony door from 8:30 to 8:50 a.m. was entered into the opening schedule.

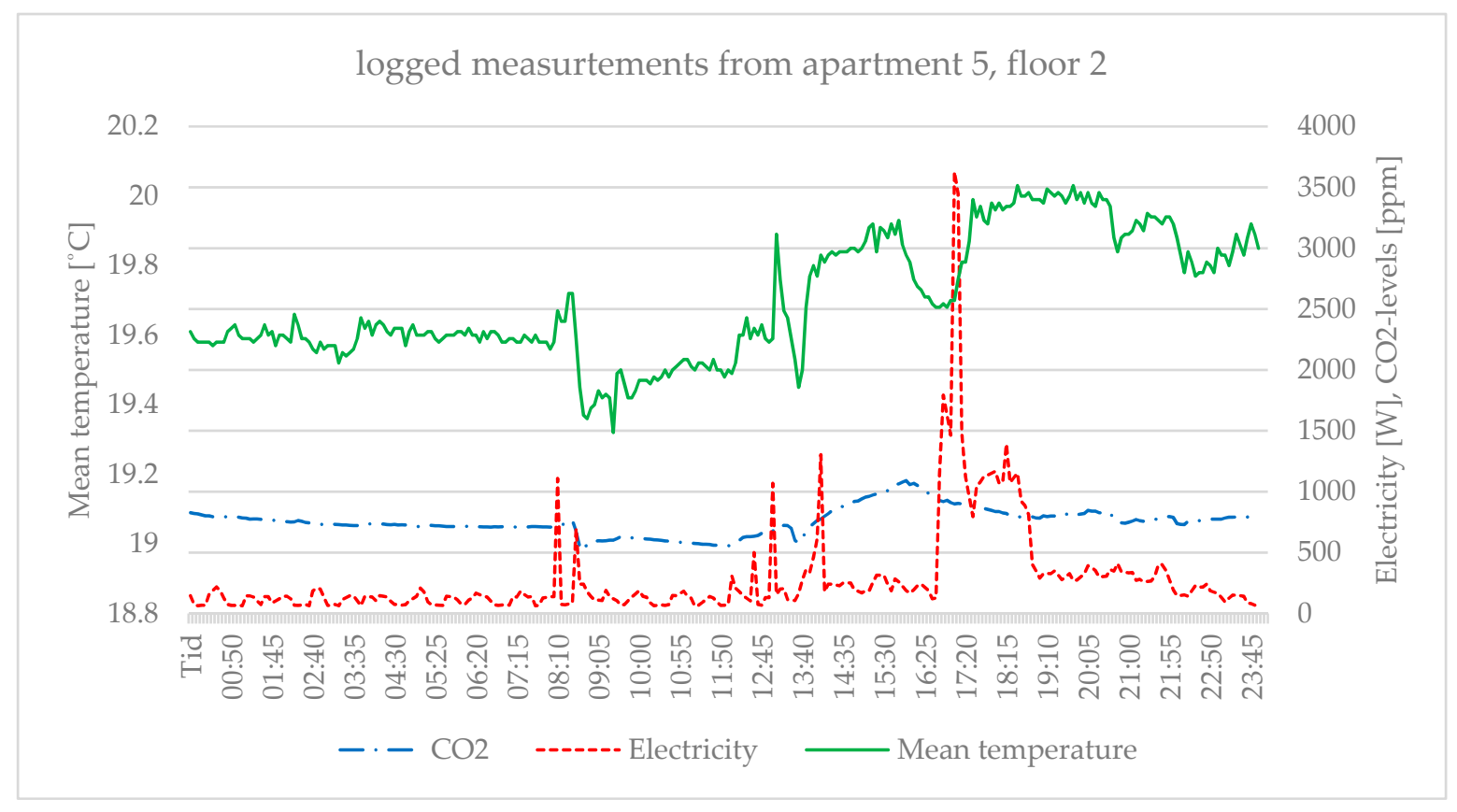

Figure 2. The logged measurements from apartment 5, second floor, on 19 November. The green (full) curve shows temperature, the blue (dotted and dashed) curve shows $\mathrm{CO}_{2}$ level, and the red (dashed) curve shows electric power. 
Table 7. Input data for BES-ref and BES-v.2.

\begin{tabular}{|c|c|c|c|c|c|c|c|c|c|}
\hline \multirow{2}{*}{$\begin{array}{c}\text { Input data } \\
\text { Apartment } 1\end{array}$} & \multicolumn{3}{|c|}{ Floor 1} & \multicolumn{3}{|c|}{ Floor 2} & \multicolumn{3}{|c|}{ Floor 3} \\
\hline & BES-ref & BES-v.2 & Difference & BES-ref & BES-v.2 & Difference & BES-ref & BES-v.2 & Difference \\
\hline Tenant electricity use/year (kWh) & 2489 & 1098 & $-56 \%$ & 3000 & 918 & $-69 \%$ & 3000 & 1098 & $-63 \%$ \\
\hline Number of people in apartment & 2 & 2 & - & 1 & 1 & - & 2 & 2 & - \\
\hline Temperature set-point $\left({ }^{\circ} \mathrm{C}\right)$ & 21.45 & 21.5 & 0.05 & 21.2 & 21.3 & 0.10 & 21.3 & 21.35 & 0.05 \\
\hline AHU schedule & Always on & Always on & - & Always on & Always on & - & Always on & Always on & - \\
\hline Zone area $\left(\mathrm{m}^{2}\right)$ & 83 & 83 & - & 100 & 100 & - & 100 & 100 & - \\
\hline \multicolumn{10}{|l|}{ Apartment 2} \\
\hline Tenant electricity use (kWh) & 2311 & 1859 & $-20 \%$ & 2311 & 1858 & $-20 \%$ & 2311 & 1849 & $-20 \%$ \\
\hline Number of people in apartment & 1 & 1 & - & 2 & 2 & - & 2 & 2 & - \\
\hline Heat exchanger efficiency (\%) & 60 & 55 & -5.00 & 60 & 55 & -5.00 & 60 & 50 & -10.0 \\
\hline Temperature set-point $\left({ }^{\circ} \mathrm{C}\right)$ & 19.8 & 19.9 & 0.10 & 19.6 & 19.8 & 0.20 & 21 & 21 & 0.00 \\
\hline AHU schedule & Always on & Always on & - & Always on & Always on & - & Always on & Always on & - \\
\hline Zone area $\left(\mathrm{m}^{2}\right)$ & 77.5 & 77.5 & - & 77.5 & 77.5 & - & 77.5 & 77.5 & - \\
\hline \multicolumn{10}{|l|}{ Apartment 3} \\
\hline Tenant electricity use (kWh) & 2311 & 1714 & $-26 \%$ & 2311 & 645 & $-72 \%$ & 2311 & 1629 & $-30 \%$ \\
\hline Number of people in apartment & 1 & 1 & - & 2 & 2 & - & 1 & 1 & - \\
\hline Temperature set-point $\left({ }^{\circ} \mathrm{C}\right)$ & 19.6 & 19.6 & 0.00 & 20.3 & 20.3 & 0.00 & 21.5 & 21.6 & 0.10 \\
\hline AHU schedule & Always on & Always on & - & Always on & Always on & - & Always on & Always on & - \\
\hline Zone area $\left(\mathrm{m}^{2}\right)$ & 77.5 & 77.5 & - & 77.5 & 77.5 & - & 77.5 & 77.5 & - \\
\hline \multicolumn{10}{|l|}{ Apartment 4} \\
\hline Tenant electricity use (kWh) & 1982 & 1389 & $-30 \%$ & 1982 & 1848 & $-7 \%$ & 1982 & 456 & $-77 \%$ \\
\hline Number of people in apartment & 1 & 1 & - & 2 & 2 & - & 1 & 1 & - \\
\hline Heat exchanger efficiency (\%) & 60 & 60 & 0.00 & 60 & 50 & -10.0 & 60 & 60 & 0.00 \\
\hline Temperature set-point $\left({ }^{\circ} \mathrm{C}\right)$ & 21.5 & 21.6 & 0.10 & 21 & 21 & 0.00 & 20.3 & 20.4 & 0.10 \\
\hline AHU schedule & Always On & Always On & - & Always On & Always On & - & Always On & Always On & - \\
\hline Zone area $\left(\mathrm{m}^{2}\right)$ & 66 & 66 & - & 66 & 66 & - & 66 & 66 & - \\
\hline
\end{tabular}


Table 7. Cont.

\begin{tabular}{|c|c|c|c|c|c|c|c|c|c|}
\hline Input data & & Floor 1 & & & Floor 2 & & & Floor 3 & \\
\hline \multicolumn{10}{|l|}{ Apartment 5} \\
\hline Tenant electricity use (kWh) & 1562 & 2852 & $83 \%$ & 1978 & 789 & $-60 \%$ & 1978 & 744 & $-62 \%$ \\
\hline Number of people in apartment & 1 & 1 & - & 1 & 1 & - & 1 & 1 & - \\
\hline Heat exchanger efficiency (\%) & 60 & 60 & 0.00 & 60 & 60 & 0.00 & 60 & 50 & -10.0 \\
\hline Temperature set-point $\left({ }^{\circ} \mathrm{C}\right)$ & 18.5 & 18.75 & 0.25 & 18.7 & 18.6 & -0.10 & 20 & 20.1 & 0.10 \\
\hline AHU schedule & Always on & Tenant-specific & - & Always on & Always on & - & Always on & Always on & - \\
\hline Zone area $\left(\mathrm{m}^{2}\right)$ & 53 & 53 & - & 66 & 66 & - & 66 & 66 & - \\
\hline Schedules for all apartments & BES-ref & BES-v.2 & & BES-ref & BES-v.2 & & BES-ref & BES-v.2 & \\
\hline occupancy schedule & $\begin{array}{l}\text { absent 7:00 a.m. } \\
\text { to 5:00 p.m. }\end{array}$ & Tenant-specific & & $\begin{array}{l}\text { absent 7:00 a.m. } \\
\text { to 5:00 p.m. }\end{array}$ & Tenant-specific & & $\begin{array}{l}\text { absent 7:00 a.m. } \\
\text { to 5:00 p.m. }\end{array}$ & Tenant-specific & \\
\hline Ventilation air flows $\left(\mathrm{L} / \mathrm{s} \cdot \mathrm{m}^{2}\right)$ & 0.4 in, 0.42 out & 0.4 in, 0.42 out & & $0.4 \mathrm{in}, 0.42$ out & 0.4 in, 0.42 out & & 0.4 in, 0.42 out & 0.4 in, 0.42 out & \\
\hline $\begin{array}{c}\text { Domestic hot water use } \\
\left(\mathrm{L} / \mathrm{m}^{2} \text {.year }\right)\end{array}$ & 345 & 345 & & 345 & 345 & & 345 & 345 & \\
\hline Airing & $4 \mathrm{kWh} / \mathrm{m}^{2} \cdot$ Year & Tenant-specific & & $4 \mathrm{kWh} / \mathrm{m}^{2} \cdot$ Year & Tenant-specific & & $4 \mathrm{kWh} / \mathrm{m}^{2} \cdot$ year & Tenant-specific & \\
\hline
\end{tabular}


Table 8. Transcribed time diary from tenant in apartment 5, second floor, on 19 November. The effects of entries on the gray background are clearly visible in the logged measurements in Figure 2.

\begin{tabular}{|c|c|c|c|c|c|}
\hline Time & Activity & Place & With Whom & Electrical Appliances & Comments \\
\hline 07:30 a.m. & Wakes up, turns on radio & Bedroom & Alone & Radio & \\
\hline 08:15 a.m. & Turns off radio, gets out of bed & Bedroom & Alone & Radio & \\
\hline 08:16 a.m. & $\begin{array}{l}\text { Turns on radio, feeds the cats, } \\
\text { makes tea }\end{array}$ & Kitchen & Alone & Water boiler 4 min, radio & \\
\hline 08:22 a.m. & Showers and gets dressed & Bathroom & Alone & & \\
\hline 08:30 a.m. & Hangs out linens on the balcony & Balcony/living room & Alone & & \\
\hline 08:30-08:50 a.m. & Opens balcony door & & & & Cats wanted to be out \\
\hline 08:40 a.m. & Empties litter box & Bathroom & Alone & Lamp & \\
\hline 08:45 a.m. & Makes breakfast, eats breakfast & Kitchen & Alone & Lamp, microwave (4 min) & \\
\hline 09:20 a.m. & Brushes teeth & Bathroom & Alone & Electrical toothbrush & \\
\hline 09:30 a.m. & $\begin{array}{l}\text { Takes in the linens and makes } \\
\text { the bed }\end{array}$ & Balcony/bedroom & Alone & & \\
\hline 09:35 a.m. & Turns off the radio & Kitchen & & Radio & \\
\hline 09:35 a.m.-12:00 p.m. & Not at home & Out & & & \\
\hline 12:00 p.m. & $\begin{array}{c}\text { Home again, turns on radio, } \\
\text { washes hands, puts groceries in } \\
\text { fridge }\end{array}$ & Kitchen & Alone & Radio & \\
\hline 12:10 p.m. & Makes copies and laminates & Bedroom/kitchen & Alone & $\begin{array}{l}\text { Copying machine, } \\
\text { laminator }\end{array}$ & \\
\hline 12:20 p.m. & At computer, talks on the phone & Bedroom & Alone & Computer, cell phone & \\
\hline 12:40 p.m. & Toilet & Bathroom & Alone & & \\
\hline 12:42 p.m. & $\begin{array}{l}\text { Heats and eats food, does } \\
\text { dishes }\end{array}$ & Kitchen & Alone & Microwave (3 min) & \\
\hline 1:05 p.m. & Empties litter box, vacuums & Bathroom & Alone & Lamp, vacuum cleaner & \\
\hline 1:10 p.m. & Vacuums & $\begin{array}{l}\text { Kitchen, living room, } \\
\text { bedroom }\end{array}$ & Alone & Vacuum cleaner & \\
\hline 1:20 p.m. & Talks on the phone & Kitchen & Alone & Cell phone & \\
\hline 1:25 p.m. & Turns on lamps in windows & Kitchen, living room & Alone & Lamps & \\
\hline 1:26-1:40 p.m. & Lights lantern & Balcony & Alone & & $\begin{array}{l}\text { Balcony door open; cats } \\
\text { outside }\end{array}$ \\
\hline 1:40 p.m. & Calls hair salon & Kitchen & Alone & Cell phone & \\
\hline
\end{tabular}


Table 8. Cont.

\begin{tabular}{|c|c|c|c|c|c|}
\hline Time & Activity & Place & With Whom & Electrical Appliances & Comments \\
\hline 1:45 p.m. & $\begin{array}{l}\text { Has a guest at home, has coffee, } \\
\text { talks, gets help with computer }\end{array}$ & & Friend & $\begin{array}{c}\text { Computer, water boiler (4 } \\
\text { min) }\end{array}$ & $\begin{array}{l}\text { Very nice with good } \\
\text { company }\end{array}$ \\
\hline 4:05 p.m. & Toilet & Bathroom & Alone & & \\
\hline 4:10 p.m. & Turns off radio and kitchen lamp & Kitchen & Alone & & \\
\hline 4:10 p.m. & Goes for a walk & Out & & & Nice with a walk \\
\hline 5:00 p.m. & $\begin{array}{c}\text { Turns on radio, starts to make } \\
\text { dinner }\end{array}$ & Kitchen & Alone & Radio, stove (17-19 min) & \\
\hline 5:15 p.m. & Copies & Bedroom & Alone & Copying machine & \\
\hline 5:25 p.m. & Does the dishes & Kitchen & Alone & Lamp & \\
\hline 5:40 p.m. & Goes through the mail & Kitchen & Alone & Lamp & \\
\hline 5:50 p.m. & Cleans toilet & Bathroom & Alone & & \\
\hline 6:00 p.m. & $\begin{array}{l}\text { Turns off radio, turns on floor } \\
\text { lamp, watches television (TV) }\end{array}$ & Living room & Alone & $\mathrm{TV}$, radio, lamp & \\
\hline 7:00 p.m. & Eats, does dishes, cleans stove & Kitchen & Alone & & \\
\hline 7:00-7:45 p.m. & Charges cell phone & & & Cell phone & \\
\hline 8:05 p.m. & Watches TV & Living room & Alone & TV & \\
\hline 8:10 p.m. & Answers an e-mail & Bedroom & Alone & Computer & \\
\hline $\begin{array}{l}\text { 8:15-10:00 p.m. } \\
\text { 8:40-8:46 p.m. }\end{array}$ & $\begin{array}{c}\text { Watches TV } \\
\text { Opens balcony door }\end{array}$ & Living room & Alone & TV & $\begin{array}{l}\text { Puts on thick socks } \\
\text { Cats wanted to be ou }\end{array}$ \\
\hline 10:00 p.m. & Empties litter box, washes hands & Bathroom & Alone & & \\
\hline 10:03 p.m. & Puts out lantern & Balcony & Alone & & $\begin{array}{c}\text { Balcony door open } \\
\text { 10:03-10:09 }\end{array}$ \\
\hline 10:04 p.m. & Makes the bed & Bedroom & Alone & & \\
\hline 10:10 p.m. & Cuddles with cat & Kitchen & Alone & & \\
\hline 10:20 p.m. & Brushes teeth & Bathroom & Alone & Electrical toothbrush & \\
\hline 10:25 p.m. & Goes through some papers & Kitchen & Alone & & \\
\hline 10:59 p.m. & Gets ready for bed & Bathroom & Alone & & \\
\hline 11:15 p.m. & Turns off all lights and goes to bed & & Alone & & Finally in bed \\
\hline
\end{tabular}


At around 9:30 a.m., we can see that the $\mathrm{CO}_{2}$ level slightly decreased, and it coincided with the tenant leaving the apartment and returning around 12:00 p.m., which is written in the time diary. The occupancy schedule was updated according to measurements and time diary entries. When the tenant returned around 12:00 p.m., one can see that both the temperature and $\mathrm{CO}_{2}$ levels started to increase; then, there was a drop around 1:30 p.m., which once again can be traced to the opening of the balcony door. Another observation was that the $\mathrm{CO}_{2}$ level increased even more and it peaked at around 4:00 p.m. This can be traced to the tenant having a friend over, which she also wrote in her time diary. This was modeled by inserting an extra occupant into the zone, who was only present from 1:45-4:00 p.m. on Wednesday. The peaks in electricity use can be traced to the tenant using the microwave, water boiler, and stove. The base load is most likely from the fridge and also the ventilation system, which is connected to the tenant's electricity since each apartment has its own ventilation system (this conclusion was based on the fact that the base load was approximately the same in each apartment). The electricity schedule was created by reading the maximum amount of power and inserting equipment with the same maximum power into the zone in the model. The schedules were made for one week. If there were drops in temperature in the logged measurements, but no entry in the time diaries of any specific behavior that could be linked to a drop in temperature, these drops were considered to be due to airing. In cases where occupancy could not be determined by time diaries, it was determined by drops and peaks in the logged measurements of $\mathrm{CO}_{2}$ level.

\subsubsection{Validation and Calibration of BES-ref and BES-v.2}

The process of calibrating the schedules for electricity use, airing, and occupancy was then done. The schedule for electricity use was altered slightly after each simulation so that the simulated graph eventually mimicked the graph from the measurements as closely as possible, and the total amount of used electricity for each day was compared to the total simulated electricity use for the same day after each simulation, making sure that they matched. In the same way, the airing and occupancy schedules were slightly altered after each simulation until the simulated temperature and $\mathrm{CO}_{2}$ graphs corresponded with the measured temperature and $\mathrm{CO}_{2}$ graphs in a satisfying way (see Figure 3). The simulated mean temperature for the week was also checked against the measured mean temperature to make sure that they corresponded. The validation criteria for mean indoor temperature was $\pm 0.1^{\circ} \mathrm{C}$ for both BES-ref and BES-v.2, while the criteria for highest and lowest indoor temperature was $\pm 0.1^{\circ} \mathrm{C}$ for BES-v. 2 if it was feasible. For electricity use, it was $\pm 5 \% \mathrm{kWh}$, and, for the start and end time of drops and peaks in temperature, $\mathrm{CO}_{2}$ levels, and electricity use, it was $\pm 30 \mathrm{~min}$. The same procedure was performed for each apartment and its corresponding zone in the model.

As can be seen in Figure 3, the $\mathrm{CO}_{2}$ levels in the simulations are somewhat lower than the measurements, but the curves have a very similar shape. This was the same for all apartments, both in BES-ref and BES-v.2, and is probably due to a higher background level of $\mathrm{CO}_{2}$ in the measurements than that which was used in the simulations. This, however, does not interfere much with the results since the objective in this study was not to compare simulated $\mathrm{CO}_{2}$ levels to measurements, but rather to compare them to other simulated results, and the $\mathrm{CO}_{2}$ measurements were used as a guide to see that the occupancy and airing schedules were done properly. 


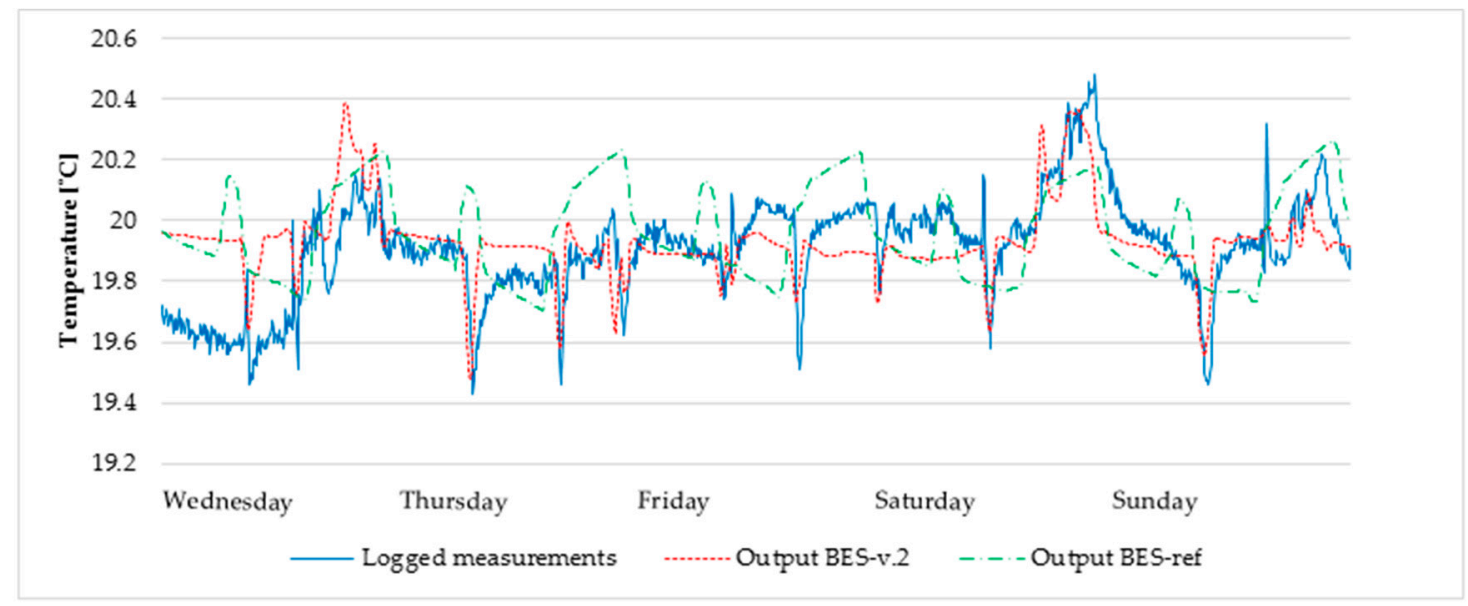

(a)

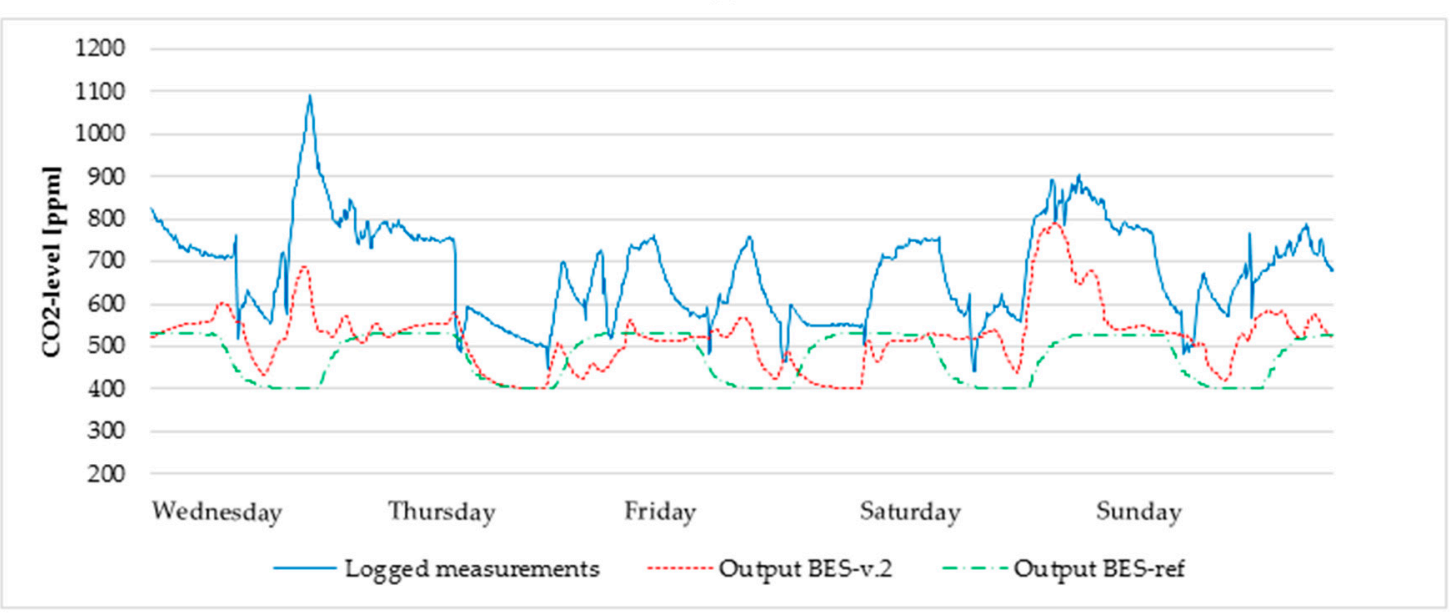

(b)

Figure 3. Logged measurements compared to simulated output from apartment 5 on the second floor, for both reference building energy simulation (BES-ref) and building energy simulation version 2 (BES-v.2), from Wednesday 19 November to Sunday 23 November: (a) mean temperature; (b) $\mathrm{CO}_{2}$ levels.

The validation of the BES models was done with empirical validation. BES-ref was validated against mean indoor temperature from the measurements, and BES-v. 2 was validated against temperature and $\mathrm{CO}_{2}$ graphs from the measurements, making sure that the graphs from the simulations followed the graphs from the measurements as described above. The validation and calibration process used in this study can be seen in Figure 4. 


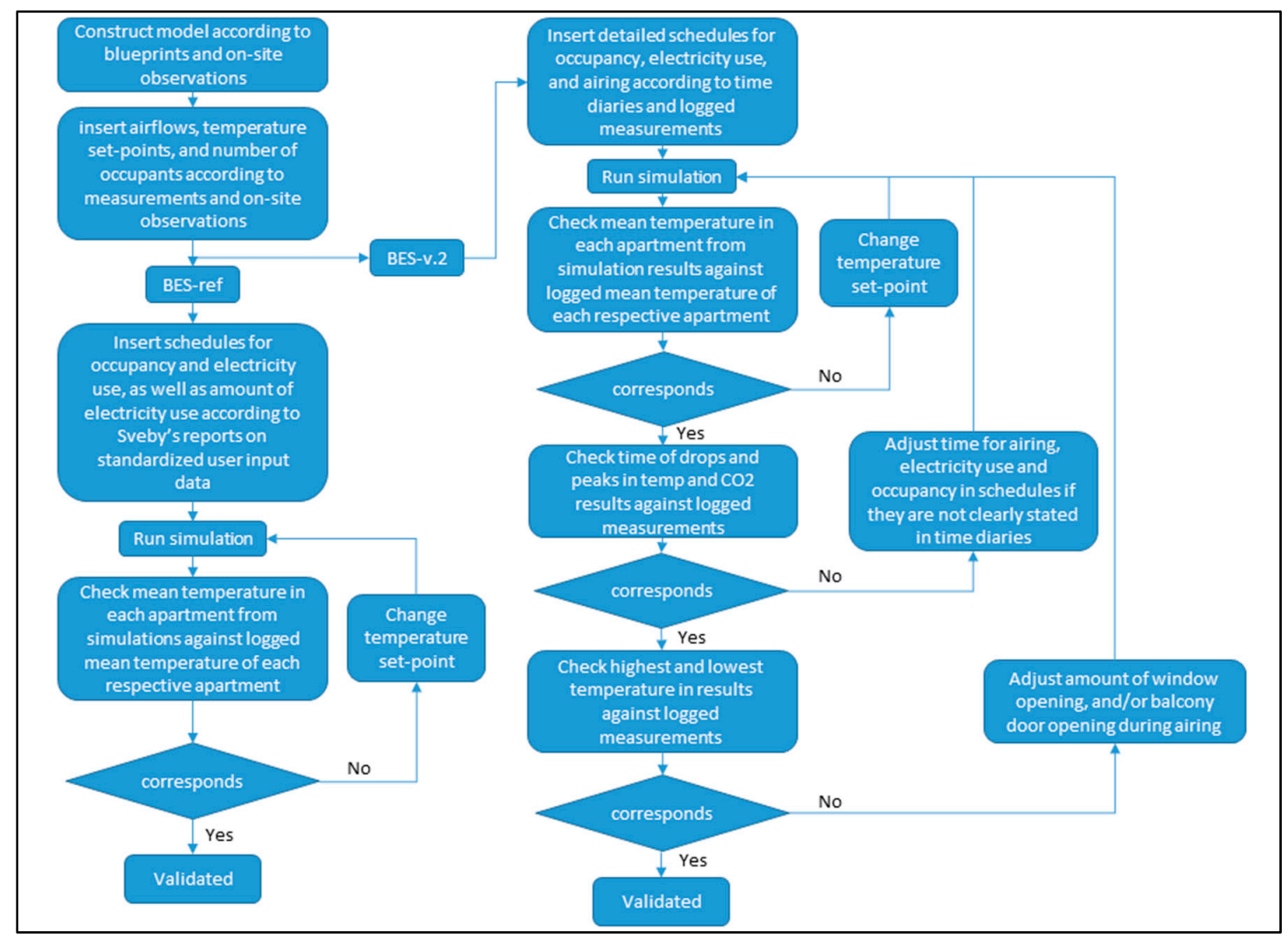

Figure 4. The validation process for BES-ref and BES-v.2 models.

\subsubsection{Comparison of the Two Models}

After both models were validated, several simulations were conducted, and the two models were compared at three different levels: (1) building level, (2) apartment level, and (3) room level. This meant that all apartments were originally modeled as one zone; however, to compare at room level, one apartment was later modeled with separate zones for each room (see Figure 5). The parameters that were compared at each level can be seen in Table 9.

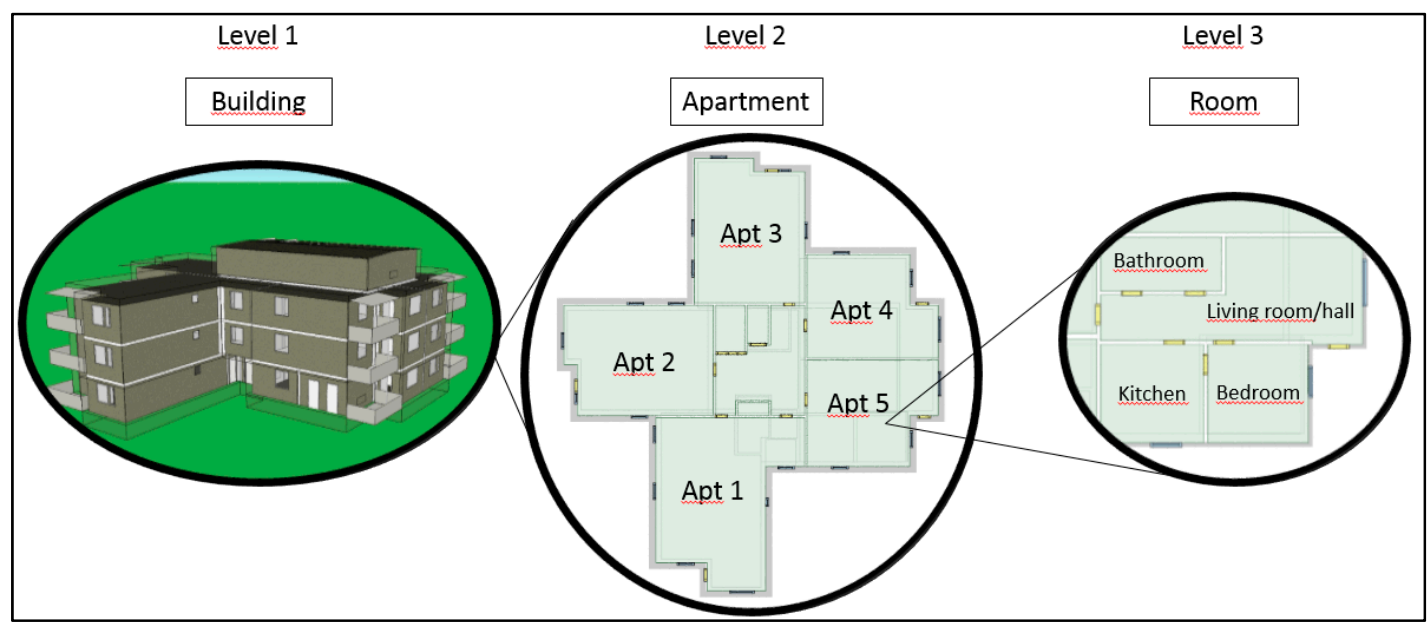

Figure 5. The three different levels on which simulated results between BES-ref and BES v.2 were compared. 
Table 9. This table describes which parameters were compared between reference BES (BES-ref) and BES version 2 (BES-v.2) at each level.

\begin{tabular}{cccc}
\hline Parameter & Level 1 Building & Level 2 Apartment & Level 3 Room \\
\hline Energy supplied by water radiators & $\mathrm{X}$ & $\mathrm{X}$ & $\mathrm{X}$ \\
(District Heating) & $\mathrm{X}$ & $\mathrm{X}$ & $\mathrm{X}$ \\
Air Handling Unit heating (electrical) & $\mathrm{X}$ & $\mathrm{X}$ & $\mathrm{X}$ \\
Energy losses due to airing & & $\mathrm{X}$ & \\
Indoor temperature & & $\mathrm{X}$ & $\mathrm{X}$ \\
$\mathrm{CO}_{2}$ level & & $\mathrm{X}$ \\
\hline PPD (Predicted Percentage Dissatisfied) & $\mathrm{X}$ & $\mathrm{X}$ & $\mathrm{X}$ \\
\hline Simulation Period & & $\mathrm{C}$ & \\
\hline Full-year simulation & &
\end{tabular}

$\mathrm{X}$ : Parameter that is compared between the models.

\section{Results and Discussion}

\subsection{Measurements, Interviews, and Time Diaries}

The mean temperature in the 12 apartments varied between $19.5^{\circ} \mathrm{C}$ in the coldest apartment to $22.1^{\circ} \mathrm{C}$ in the warmest apartment during the measuring period. This may seem odd; however, in interviews, some of the tenants stated that they used to turn down their radiators since they liked it a bit cooler inside. Domestic hot-water use was calculated from the total use for the city block to $345 \mathrm{~L} / \mathrm{m}^{2}$ and year, which led to a total energy use for heating of water as $34.9 \mathrm{MWh}$ in the modeled building. From all 12 apartments, logged measurements of indoor temperature, $\mathrm{CO}_{2}$ levels, relative humidity, and electricity use were collected for a week, and results from 19 November in apartment 5 on the second floor can be seen in Figure 2 (see Figure 5 for construction plan).

The level of detail in the time diaries varied between the different apartments, and one day from one of the most detailed time diaries was transcribed, as can be seen in Table 8. This is the time diary written by the tenant of the apartment from which the measurements in Figure 2 were collected. It is also from the same day, 19 November, as the results in Figure 2.

From the time diaries and the measurements, clear patterns could be seen for each household. Even though the patterns differed between the households, some clear differences compared to the general population of Sweden, henceforth called the general population, could be seen. For instance, many of them stated during the interviews and/or wrote in their time diaries that they aired their apartments a couple of times a day to get fresh air in. This could be seen in the measurements as drops in temperature and $\mathrm{CO}_{2}$ levels. This behavior is something that seems to be connected to something they "used to do" in their old house or apartment. As stated earlier, most of the tenants are over 65 years old and moved to this city block upon getting older; thus, this is probably a behavior that they grew up with, since it was common practice in Sweden to ventilate homes in this way. They also stayed at home for a longer time each day than the general population. The tenants are at home for approximately $20 \mathrm{~h} /$ day in this case, which is a difference of $6 \mathrm{~h} /$ day compared to Sveby's user input data, which say that occupancy should be entered as $14 \mathrm{~h} /$ day. This was expected and does not seem strange since it is a retirement home and most of the tenants do not work anymore. If the household electricity use, which was read weekly for two months, is scaled up to be the same use for an entire year, this will also show large differences compared to the general population. The tenants in this study had an electricity use of approximately $19 \mathrm{kWh} / \mathrm{m}^{2}$.year, while Sveby's standard user input data say $30 \mathrm{kWh} / \mathrm{m}^{2}$.year for the general population. The reasons for this might be many, but the most probable cause is that, since this is an elderly population, they do not seem to own as many electrical appliances as the general population. According to Sveby's reports of user input data [36], electricity use can differ by around $30 \%$ between the summer and winter. This is, among other things, due to the large 
difference in daylight and the fact that people spend more time indoors during winter, since Sweden is situated in the northern part of the temperate and polar climate zone. This means that the difference between the occupants in the study and the regular population might differ even more since they probably have an even lower electricity use during the summer.

\subsection{Comparing BES-ref to BES-v.2}

\subsubsection{Building Level}

At building level, the simulated values of energy for space heating, electricity use, and energy loss due to airing were compared between BES-ref and BES v.2. The results show an increase in energy supplied by water radiators, district heating $(\mathrm{DH})$, with $20 \%$, an increase in air handling unit (AHU) heating (electrical) with $85 \%$, a decrease in tenant electricity use with $39 \%$ (this is an input value, see Table 7), and an increase in energy loss due to airing with 99\%from BES-ref to BES v.2 (see Table 10).

Table 10. Simulated values for a whole-year simulation at building level from BES-ref and BES v.2, and difference in percentage between them (unit KWh).

\begin{tabular}{cccc}
\hline Parameter & BES-ref & BES-v.2 & Difference BES-ref to BES-v.2 \\
\hline Energy supplied by water radiators (DH) & 48,545 & 58,345 & $20 \%$ \\
AHU heating (electrical) & 3432 & 6357 & $85 \%$ \\
Total energy use for space heating & 51,976 & 64,702 & $24 \%$ \\
Energy loss due to airing & 5464 & 10,865 & $99 \%$ \\
Household electricity (input) & 34,092 & 20,659 & $-39 \%$ \\
\hline
\end{tabular}

The two things that really stand out are losses due to airing and the increase in heating from the AHU. The reasons for the increase in electrical heating from the AHU can be traced back to the difference in input data between the two models. In many apartments, the efficiency of the heat exchanger was lowered after measurements showed a higher electricity baseload in these apartments that could only be traced to the AHU. In apartment 1 on the second floor, the heater in the AHU was set a lot higher than in the remaining apartments, which gave the tenant a temperature of $20^{\circ} \mathrm{C}$ in the supply air from the AHU (this was entered into BES-v.2); this also led to a higher electricity use from the AHU. The difference in the amount of energy losses from airing might seem odd at a first glance; however, taking into account that, according to time diaries and interviews, they seem to air a lot more than the general population, it does not seem as odd anymore. However, this type of airing should not be needed in a building with an exhaust and supply air ventilation system with heat recovery. In a previous study of the same building block made by Carlander and Tullsson [37], where they conducted a survey using questionnaires of indoor climate, they got evidence pointing out that the AHUs do not work as well as they are supposed to, which might also contribute to more excessive airing than usual. The difference could also be due to the fact that the schedules could only be validated for one specific week in each apartment, but the schedules were then also used for full-year simulations; thus, it is possible that the tenants air less during colder days and more during warmer days. However, since the measurements and time diaries were all done during the heating season, the authors are confident that the tenants air quite a lot even during this period. The third interesting thing is the household electricity use. In BES-v.2, the input value was 39\% less than in BES-ref. The value for BES-v.2 was acquired by reading the electricity meters of each apartment, and through the logged measurements. The input value of household electricity for BES-ref was taken from Sveby's reports on standardized user input data. As can be seen, the standardized user input data are much higher than the actual use in this case. Electricity use can be $30 \%$ higher than average during the winter and $30 \%$ less than average during the summer according to Reference [10]. If this applies for the tenants in this case, it means even less internal gains during the summer and, therefore, probably even higher energy use for space heating. The tenants are, however, home a lot more than the average population. This means 
higher internal gains from occupancy than what you get from using template values; however, in the end, there was still a difference in total energy use for space heating of $24 \%$ between the two models, where BES-v.2 had the highest use.

\subsubsection{Apartment Level}

When analyzing the models on an apartment level, quite big differences can be seen between the two models (BES-ref and BES-v.2), as well as between the apartments themselves, especially in BES-v.2. The results from the five-day simulation periods can be seen in Table 11, and the results for the full-year simulation can be seen in Table 12. The apartment with the biggest difference in total energy use for space heating between BES-ref and BESv.2 was apartment 5 on the second floor, which is the apartment with the tenant who made the most detailed time diary. The difference in total energy use for space heating in this apartment was $170 \%$ according to the simulations. This seems to be due to the fact that she is one of the tenants with the lowest indoor temperature, which means that the BES-ref model of this apartment hardly used any energy for space heating at all (only $6.6 \mathrm{kWh}$ including losses due to airing in the five-day simulation period). However, when airing, occupancy, and schedules for electricity use according to logged measurements and the time diary were added, the energy use for space heating increased with $329 \%$. This is a product of the tenant using about $60 \%$ less electricity, and airing quite a lot more in BES-v.2 than in BES-ref. However, this tenant is not the one that seems to be doing the most airing. In the apartment with the highest losses due to airing, the difference between BES-ref and BES-v. 2 was $991 \%$. This, however, might not be as strange as it sounds, as the tenants in this apartment wrote in their time diary that they always had a window open during the night when they were sleeping, which can be seen quite clearly in the temperature measurements from their apartment. A distinct pattern of dropping temperature during the nights can be seen in Figure 6, which corresponds to the tenants' entry of opening windows in their time diary. Figure 6 also shows the simulated temperature curves from the models BES-ref and BES-v.2. The temperature curve from BES-v.2 follows the logged measurement curve in a good way, while the curve from BES-ref has much less fluctuation in temperature compared to the logged measurements and BES-v.2.

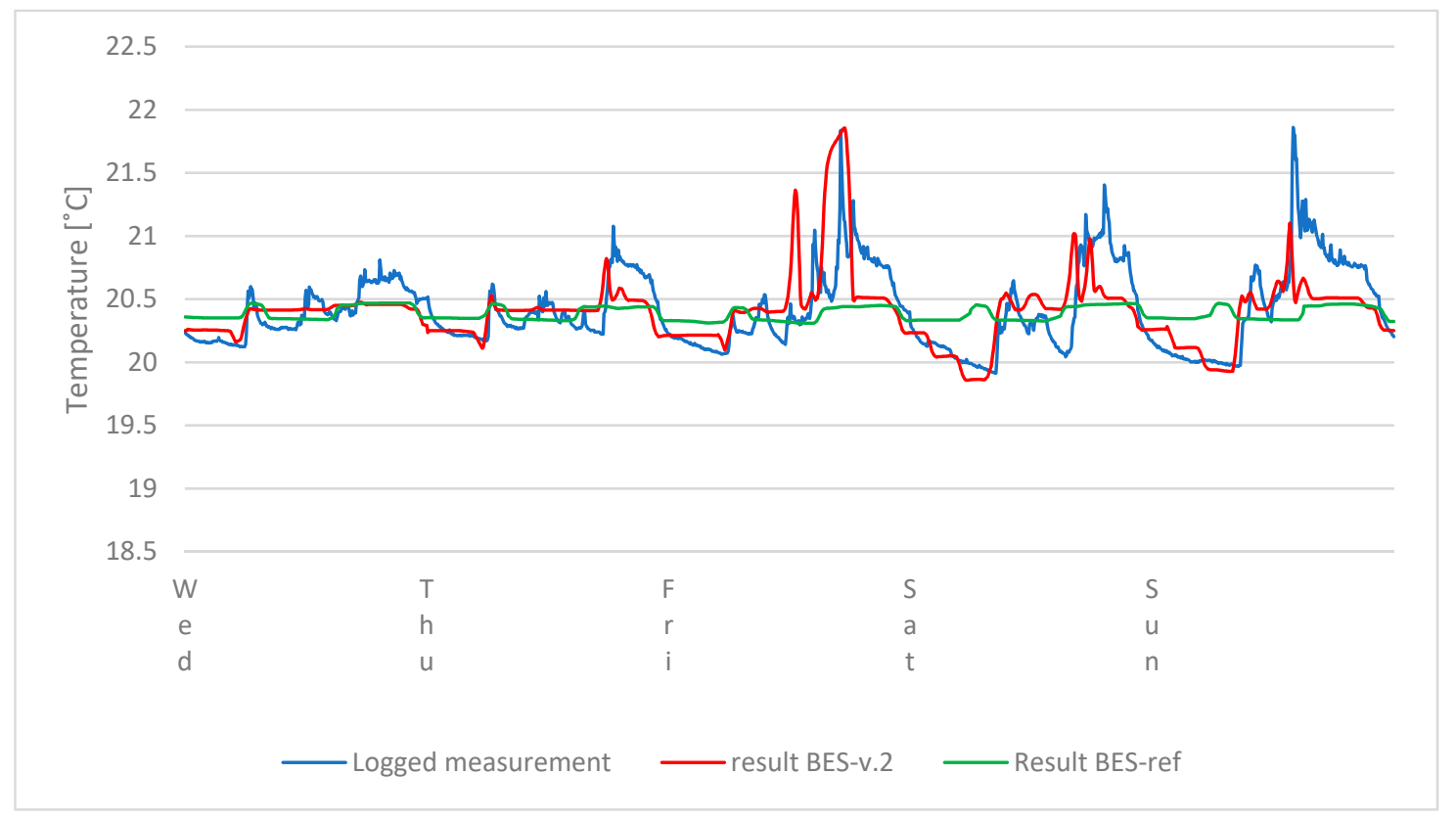

Figure 6. Temperature curves from logged measurements, BES-ref, and BES-v.2 for the period of 21-25 January. The blue curve shows the logged measurements, the red curve shows results from BES-v.2, and the green curve shows results from BES-ref. 
Table 11. Results at the apartment level from simulations using the two models (BES-ref and BES-v.2). The simulations were done for the same period as the logged measurements, and the time diaries were done for each apartment.

\begin{tabular}{|c|c|c|c|c|c|c|c|c|c|}
\hline \multirow{2}{*}{ Parameters } & \multicolumn{3}{|c|}{ Floor 1} & \multicolumn{3}{|c|}{ Floor 2} & \multicolumn{3}{|c|}{ Floor 3} \\
\hline & BES-ref & BES-v.2 & Difference & BES-ref & BES-v.2 & Difference & BES-ref & BES-v.2 & Difference \\
\hline Apartment 1 & \multicolumn{3}{|c|}{ Simulation period 10 to 14 December 2014} & \multicolumn{3}{|c|}{ Simulation period 14 to 18 January 2015} & \multicolumn{3}{|c|}{ Simulation period 10 to 14 December 2014} \\
\hline $\begin{array}{l}\text { Energy supplied by water } \\
\text { radiators }(\mathrm{DH})(\mathrm{kWh})\end{array}$ & 127.5 & 137.4 & $8 \%$ & 83 & 90.3 & $9 \%$ & 101.3 & 115.8 & $14 \%$ \\
\hline AHU heating (electrical) (kWh) & 3.4 & 3.6 & $6 \%$ & 4.9 & 11.4 & $133 \%$ & 4.2 & 4.2 & $0 \%$ \\
\hline $\begin{array}{c}\text { Total energy use for space } \\
\text { heating }(\mathrm{kWh})\end{array}$ & 130.9 & 141 & $8 \%$ & 87.9 & 101.7 & $16 \%$ & 105.5 & 120 & $14 \%$ \\
\hline Energy loss due to airing ( $\mathrm{kWh}$ ) & 4.6 & 4 & $-13 \%$ & 5.5 & 5.9 & $7 \%$ & 5.5 & 1.4 & $-75 \%$ \\
\hline Indoor temperature $\left({ }^{\circ} \mathrm{C}\right)$ & $22.0-22.1$ & $21.8-22.1$ & - & $21.8-22.0$ & $21.0-22.0$ & - & $21.9-22.0$ & $21.9-22.1$ & - \\
\hline Maximum $\mathrm{CO}_{2}(\mathrm{ppm})$ & 670.7 & 672.7 & 2.0 & 512.5 & 594.9 & 82.4 & 626.3 & 627.4 & 1.1 \\
\hline Maximum PPD (\%) & 13.5 & 13.9 & 0.4 & 13.3 & 14.6 & 1.3 & 12.3 & 12.3 & 0.0 \\
\hline Apartment 2 & \multicolumn{3}{|c|}{ Simulation period 21 to 25 January 2015} & \multicolumn{3}{|c|}{ Simulation period 21 to 25 January 2015} & \multicolumn{3}{|c|}{ Simulation period 10 to 14 December 2014} \\
\hline $\begin{array}{l}\text { Energy supplied by water } \\
\text { radiators }(\mathrm{DH})(\mathrm{kWh})\end{array}$ & 83.6 & 123.7 & $48 \%$ & 40.8 & 77.5 & $90 \%$ & 82.6 & 94.6 & $15 \%$ \\
\hline AHU heating (electrical) (kWh) & 14 & 19.7 & $41 \%$ & 14.3 & 19.1 & $34 \%$ & 4.1 & 13 & $217 \%$ \\
\hline $\begin{array}{c}\text { Total energy use for space } \\
\text { heating }(\mathrm{kWh})\end{array}$ & 97.6 & 143.4 & $47 \%$ & 55.1 & 96.6 & $75 \%$ & 86.7 & 107.6 & $24 \%$ \\
\hline Energy loss due to airing ( $\mathrm{kWh}$ ) & 4.3 & 46.9 & $991 \%$ & 4.3 & 38.3 & $791 \%$ & 4.3 & 12.8 & $198 \%$ \\
\hline Indoor temperature $\left({ }^{\circ} \mathrm{C}\right)$ & $20.4-20.5$ & $19.9-21.9$ & - & $20.3-20.5$ & $19.9-22.5$ & - & $21.6-21.7$ & $21.2-21.8$ & - \\
\hline Maximum $\mathrm{CO}_{2}(\mathrm{ppm})$ & 545.3 & 686.5 & 141.2 & 69.7 & 686.4 & 616.7 & 692.1 & 692.4 & 0.3 \\
\hline Maximum PPD (\%) & 23.5 & 25.5 & 2.0 & 21.5 & 23.0 & 1.5 & 13.7 & 14.4 & 0.7 \\
\hline Apartment 3 & \multicolumn{3}{|c|}{ Simulation period 3 to 7 December 2014} & \multicolumn{3}{|c|}{ Simulation period 19 to 23 November 2014} & \multicolumn{3}{|c|}{$\begin{array}{c}\text { Simulation period } 28 \text { January to } 1 \\
\text { February } 2015\end{array}$} \\
\hline $\begin{array}{l}\text { Energy supplied by water } \\
\text { radiators }(\mathrm{DH})(\mathrm{kWh})\end{array}$ & 74 & 77 & $4 \%$ & 45.4 & 69.2 & $52 \%$ & 105.8 & 136.4 & $29 \%$ \\
\hline AHU heating (electrical) (kWh) & 9.1 & 22 & $142 \%$ & 4.1 & 4.3 & $5 \%$ & 6.5 & 6.4 & $-2 \%$ \\
\hline $\begin{array}{c}\text { Total energy use for space } \\
\text { heating }(\mathrm{kWh})\end{array}$ & 83.1 & 99 & $19 \%$ & 49.5 & 73.5 & $48 \%$ & 112.3 & 142.8 & $27 \%$ \\
\hline Energy loss due to airing ( $\mathrm{kWh}$ ) & 4.3 & 4.2 & $-2 \%$ & 4.3 & 15 & $249 \%$ & 4.3 & 25 & $481 \%$ \\
\hline Indoor temperature $\left({ }^{\circ} \mathrm{C}\right)$ & $20.2-20.4$ & $20.1-20.6$ & - & $20.9-21.2$ & $20.8-21.5$ & - & $22.0-22.2$ & $22.0-22.3$ & - \\
\hline Maximum $\mathrm{CO}_{2}(\mathrm{ppm})$ & 545.1 & 689 & 143.9 & 691.3 & 689.6 & -1.7 & 546 & 579.1 & 33.1 \\
\hline Maximum PPD (\%) & 23.8 & 24.8 & 1.0 & 15.6 & 16.8 & 1.2 & 13.3 & 13.0 & -0.3 \\
\hline
\end{tabular}


Table 11. Cont.

\begin{tabular}{|c|c|c|c|c|c|c|c|c|c|}
\hline \multirow{2}{*}{ Parameters } & \multicolumn{3}{|c|}{ Floor 1} & \multicolumn{3}{|c|}{ Floor 2} & \multicolumn{3}{|c|}{ Floor 3} \\
\hline & BES-ref & BES-v.2 & Difference & BES-ref & BES-v.2 & Difference & BES-ref & BES-v.2 & Difference \\
\hline Apartment 4 & \multicolumn{3}{|c|}{ Simulation period 21 to 25 January 2015} & \multicolumn{3}{|c|}{ Simulation period 10 to 14 December 2014} & \multicolumn{3}{|c|}{ Simulation period 14 to 18 January 2015} \\
\hline $\begin{array}{l}\text { Energy supplied by water } \\
\text { radiators }(\mathrm{DH})(\mathrm{kWh})\end{array}$ & 105 & 138.9 & $32 \%$ & 48.4 & 57.8 & $19 \%$ & 46.2 & 76.5 & $66 \%$ \\
\hline AHU heating (electrical) ( $\mathrm{kWh})$ & 8.4 & 8.5 & $1 \%$ & 3.5 & 11.1 & $217 \%$ & 5.1 & 5.1 & $0 \%$ \\
\hline $\begin{array}{c}\text { Total energy use for space } \\
\text { heating }(\mathrm{kWh})\end{array}$ & 113.4 & 147.4 & $30 \%$ & 51.9 & 68.9 & $33 \%$ & 51.3 & 81.6 & $59 \%$ \\
\hline Energy loss due to airing ( $\mathrm{kWh}$ ) & 3.6 & 27.5 & $664 \%$ & 3.6 & 10.2 & $183 \%$ & 3.6 & 14.7 & $308 \%$ \\
\hline Indoor temperature $\left({ }^{\circ} \mathrm{C}\right)$ & $22.0-22.1$ & $21.8-22.1$ & - & $21.6-21.8$ & $21.2-21.9$ & - & $20.9-21.1$ & $20.8-21.1$ & - \\
\hline Maximum $\mathrm{CO}_{2}(\mathrm{ppm})$ & 570.9 & 606.3 & 35.4 & 737.6 & 742.1 & 4.5 & 570.6 & 570.7 & 0.1 \\
\hline Maximum PPD (\%) & 14.4 & 15.0 & 0.6 & 12.7 & 13.7 & 1.0 & 16.2 & 16.6 & 0.4 \\
\hline Apartment 5 & \multicolumn{3}{|c|}{$\begin{array}{c}\text { Simulation period } 28 \text { January to } 1 \\
\text { February } 2015\end{array}$} & \multicolumn{3}{|c|}{ Simulation period 19 to 23 November 2014} & \multicolumn{3}{|c|}{ Simulation period 3 to 7 December 201} \\
\hline $\begin{array}{l}\text { Energy supplied by water } \\
\text { radiators }(\mathrm{DH})(\mathrm{kWh})\end{array}$ & 7.6 & 20.8 & $174 \%$ & 6.6 & 28.3 & $329 \%$ & 48.5 & 89.4 & $84 \%$ \\
\hline AHU heating (electrical) (kWh) & 9 & 3.1 & $-66 \%$ & 6.1 & 6 & $-2 \%$ & 7 & 14.6 & $109 \%$ \\
\hline $\begin{array}{c}\text { Total energy use for space } \\
\text { heating }(\mathrm{kWh})\end{array}$ & 16.6 & 23.9 & $44 \%$ & 12.7 & 34.3 & $170 \%$ & 55.5 & 104 & $87 \%$ \\
\hline Energy loss due to airing $(\mathrm{kWh})$ & 2.9 & 13.5 & $366 \%$ & 3.6 & 11.6 & $222 \%$ & 3.6 & 24.4 & $578 \%$ \\
\hline Indoor temperature $\left({ }^{\circ} \mathrm{C}\right)$ & 19.3-20.2 & 19.3-19.9 & - & 19.5-20.6 & 19.4-20.4 & - & $20.6-20.8$ & $20.5-20.8$ & - \\
\hline Maximum $\mathrm{CO}_{2}(\mathrm{ppm})$ & 613 & 2252 & 1639.0 & 566.3 & 714.3 & 148.0 & 566.6 & 566.8 & 0.2 \\
\hline Maximum PPD (\%) & 27.7 & 26.9 & -0.9 & 22.7 & 22.3 & -0.4 & 18.6 & 19.5 & 0.9 \\
\hline
\end{tabular}


Table 12. Results from yearly simulations at the apartment level for both models (BES-ref and BES-v.2).

\begin{tabular}{|c|c|c|c|c|c|c|c|c|c|}
\hline \multirow{2}{*}{$\begin{array}{c}\text { Parameters } \\
\text { Apartment } 1\end{array}$} & \multicolumn{3}{|c|}{ Floor 1} & \multicolumn{3}{|c|}{ Floor 2} & \multicolumn{3}{|c|}{ Floor 3} \\
\hline & BES-ref & BES-v.2 & Difference & BES-ref & BES-v.2 & Difference & BES-ref & BES-v.2 & Difference \\
\hline Energy supplied by water radiators $(\mathrm{DH})(\mathrm{kWh})$ & 4856.8 & 5386.6 & $11 \%$ & 3177.5 & 3279.1 & $3 \%$ & 3417.3 & 3993.8 & $17 \%$ \\
\hline AHU heating (electrical) $(\mathrm{kWh})$ & 188.7 & 194.7 & $3 \%$ & 240.8 & 1695.4 & $604 \%$ & 227.9 & 230.1 & $1 \%$ \\
\hline Total energy use for space heating $(\mathrm{kWh})$ & 5045.5 & 5581.3 & $11 \%$ & 3418.3 & 4974.5 & $46 \%$ & 3645.2 & 4223.9 & $16 \%$ \\
\hline Energy loss due to airing $(\mathrm{kWh})$ & 332 & 188.9 & $-43 \%$ & 400 & 217.3 & $-46 \%$ & 400 & 60.2 & $-85 \%$ \\
\hline Indoor temperature $\left({ }^{\circ} \mathrm{C}\right)$ & $21.9-31.0$ & $21.6-29.5$ & N/A & $21.6-33.0$ & $18.4-31.2$ & N/A & $21.8-33.7$ & $21.8-31.9$ & N/A \\
\hline Maximum $\mathrm{CO}_{2}(\mathrm{ppm})$ & 682.4 & 682.3 & $0 \%$ & 517.8 & 610.1 & $18 \%$ & 637.8 & 637.7 & $0 \%$ \\
\hline \multicolumn{10}{|l|}{ Apartment 2} \\
\hline Energy supplied by water radiators $(\mathrm{DH})(\mathrm{kWh})$ & 2896 & 4158.6 & $44 \%$ & 1055.1 & 1952.4 & $85 \%$ & 2859.3 & 3119.7 & $9 \%$ \\
\hline AHU heating (electrical) (kWh) & 289.9 & 442.3 & $53 \%$ & 282.3 & 432.5 & $53 \%$ & 197.4 & 490.6 & $149 \%$ \\
\hline Total energy use for space heating $(\mathrm{kWh})$ & 3185.9 & 4600.9 & $44 \%$ & 1337.4 & 2384.9 & $78 \%$ & 3056.7 & 3610.3 & $18 \%$ \\
\hline Energy loss due to airing (kWh) & 310 & 1842.6 & $494 \%$ & 310 & 798.9 & $158 \%$ & 310 & 498.7 & $61 \%$ \\
\hline Indoor temperature $\left({ }^{\circ} \mathrm{C}\right)$ & $20.3-30.5$ & $17.7-30.6$ & $\mathrm{~N} / \mathrm{A}$ & $20.2-32.5$ & $18.8-32.7$ & $\mathrm{~N} / \mathrm{A}$ & $21.5-33.0$ & $20.8-31.9$ & N/A \\
\hline Maximum $\mathrm{CO}_{2}(\mathrm{ppm})$ & 551.3 & 696.3 & $26 \%$ & 704.9 & 698.2 & $-1 \%$ & 705.6 & 705 & $0 \%$ \\
\hline \multicolumn{10}{|l|}{ Apartment 3} \\
\hline Energy supplied by water radiators $(\mathrm{DH})(\mathrm{kWh})$ & 2845 & 3129.3 & $10 \%$ & 1786.6 & 2667.5 & $49 \%$ & 3668.4 & 4557.8 & $24 \%$ \\
\hline AHU heating (electrical) $(\mathrm{kWh})$ & 307.6 & 780.7 & $154 \%$ & 242.4 & 253.5 & $5 \%$ & 169.2 & 167.5 & $-1 \%$ \\
\hline Total energy use for space heating $(\mathrm{kWh})$ & 3152.6 & 3910 & $24 \%$ & 2029 & 2921 & $44 \%$ & 3837.6 & 4725.3 & $23 \%$ \\
\hline Energy loss due to airing (kWh) & 310 & 441.9 & $43 \%$ & 310 & 797 & $157 \%$ & 310 & 782.7 & $152 \%$ \\
\hline Indoor temperature $\left({ }^{\circ} \mathrm{C}\right)$ & $20.1-30.7$ & $19.9-30.1$ & N/A & $20.8-32.7$ & $20.6-31.2$ & N/A & $21.9-33.3$ & $21.5-31.7$ & N/A \\
\hline Maximum $\mathrm{CO}_{2}(\mathrm{ppm})$ & 551.1 & 702.3 & $27 \%$ & 704.6 & 702.9 & $0 \%$ & 552.5 & 649 & $17 \%$ \\
\hline \multicolumn{10}{|l|}{ Apartment 4} \\
\hline Energy supplied by water radiators $(\mathrm{DH})(\mathrm{kWh})$ & 4068.7 & 4981.8 & $22 \%$ & 1741.4 & 1893.5 & $9 \%$ & 1692.1 & 3006.3 & $78 \%$ \\
\hline AHU heating (electrical) $(\mathrm{kWh})$ & 150.1 & 151.5 & $1 \%$ & 169.7 & 418.6 & $147 \%$ & 208.3 & 214 & $3 \%$ \\
\hline Total energy use for space heating $(\mathrm{kWh})$ & 4218.8 & 5133.3 & $22 \%$ & 1911.1 & 2312.1 & $21 \%$ & 1900.4 & 3220.3 & $69 \%$ \\
\hline Energy loss due to airing (kWh) & 264 & 734 & $178 \%$ & 264 & 403.6 & $53 \%$ & 264 & 1154 & $337 \%$ \\
\hline Indoor temperature $\left({ }^{\circ} \mathrm{C}\right)$ & $21.8-30.6$ & $21.4-29.4$ & N/A & $21.5-32.7$ & $20.9-31.6$ & $\mathrm{~N} / \mathrm{A}$ & $20.8-33.0$ & $20.5-30.9$ & N/A \\
\hline Maximum $\mathrm{CO}_{2}(\mathrm{ppm})$ & 577.1 & 614.6 & $6 \%$ & 753 & 756.9 & $1 \%$ & 578.8 & 577.8 & $0 \%$ \\
\hline \multicolumn{10}{|l|}{ Apartment 5} \\
\hline Energy supplied by water radiators $(\mathrm{DH})(\mathrm{kWh})$ & 457.5 & 641.4 & $40 \%$ & 425.9 & 587 & $38 \%$ & 1492.3 & 3009.6 & $102 \%$ \\
\hline AHU heating (electrical) $(\mathrm{kWh})$ & 244.4 & 68.86 & $-72 \%$ & 277.7 & 317.1 & $7 \%$ & 229.1 & 499.3 & $118 \%$ \\
\hline Total energy use for space heating $(\mathrm{kWh})$ & 701.9 & 710.26 & $1 \%$ & 703.6 & 904.1 & $28 \%$ & 1721.4 & 3508.9 & $104 \%$ \\
\hline Energy loss due to airing $(\mathrm{kWh})$ & 212 & 404.2 & $91 \%$ & 264 & 771.9 & $192 \%$ & 264 & 1269.3 & $381 \%$ \\
\hline Indoor temperature $\left({ }^{\circ} \mathrm{C}\right)$ & $19.2-30.6$ & $18.9-29.6$ & N/A & $19.3-33.1$ & $16.3-31.2$ & $\mathrm{~N} / \mathrm{A}$ & $20.5-33.5$ & $20.1-31.4$ & $\mathrm{~N} / \mathrm{A}$ \\
\hline Maximum $\mathrm{CO}_{2}(\mathrm{ppm})$ & 622.7 & 3120 & $401 \%$ & 574.8 & 791.7 & $38 \%$ & 575.1 & 573.3 & $0 \%$ \\
\hline
\end{tabular}


The average difference in total energy use for space heating in the 15 apartments for the five-day simulations was $47 \%$, and, for a full-year simulation, it was $37 \%$. In general, the biggest differences between the models can be found in the amount of energy loss due to airing, both in full-year simulations and in the simulations of the validation periods. Since this was also the case in the building-level simulations, no further discussion on this takes place here. To be able to see how well the two models, BES-ref and BES-v.2, could replicate the logged measurements of temperature during the measurement period, a statistical analysis was done by calculating the mean bias error (MBE), normalized mean bias error (NMBE), and coefficient of variance (CV) of the root-mean-square error (RMSE) according to Reference [38]. Table 13 shows the results of MBE, NMBE, and CV (RMSE), when comparing simulated results of temperature to logged measurements. As can be seen in Table 13, BES-v.2 had a lower MBE, NMBE, and CV (RMSE) in all cases, which shows that BES-v.2 is better for predicting indoor temperature than BES-ref. According to ASHRAE Guideline 14, the MBE for hourly data of energy use should not exceed 10, and the CV (RMSE) should not be more than 30 . In this case, the data are from every five minutes and do not represent energy use; instead, the temperature is compared. However, all values for both models were under the recommended values from ASHRAE Guideline 14 [39].

Table 13. Mean bias error (MBE), normalized mean bias error (NMBE), and coefficient of variation (CV) of the root-mean-square error (RMSE) for logged measurements of temperature and the simulated results for BES-ref and BES-v.2.

\begin{tabular}{ccccccc}
\hline Apartment and Floor & \multicolumn{3}{c}{ Logged vs. BES-ref } & \multicolumn{3}{c}{ Logged vs. BES-v2 } \\
\hline Floor 1 & MBE & NMBE & CV (RMSE) (\%) & MBE & NMBE & CV (RMSE) (\%) \\
\hline Apartment 1 & -0.068 & -0.31 & 11.7 & -0.0077 & -0.035 & 1.33 \\
Apartment 2 & 0.028 & 0.14 & 5.19 & 0.012 & 0.059 & 2.26 \\
Apartment 3 & 0.076 & 0.38 & 14.3 & 0.071 & 0.35 & 13.2 \\
Apartment 4 & 0.051 & 0.23 & 8.75 & -0.015 & -0.067 & 2.55 \\
Apartment 5 & 0.078 & 0.40 & 15.2 & -0.054 & -0.28 & 10.49 \\
\hline Floor 2 & & & & & \\
Apartment 1 & 0.032 & 0.15 & 5.54 & 0.021 & 0.098 & 3.71 \\
Apartment 2 & 0.028 & 0.14 & 5.19 & -0.0099 & -0.048 & 1.84 \\
Apartment 3 & -0.079 & -0.38 & 14.2 & -0.008 & -0.038 & 1.46 \\
Apartment 4 & 0.0084 & 0.039 & 1.48 & 0.0061 & 0.028 & 1.07 \\
Apartment 5 & -0.056 & -0.28 & 10.8 & -0.023 & -0.11 & 4.36 \\
\hline Floor 3 & & & & & & \\
\hline Apartment 1 & -0.068 & -0.31 & 11.7 & -0.0077 & -0.035 & 1.33 \\
Apartment 2 & 0.0084 & 0.039 & 1.48 & 0.0067 & 0.31 & 1.18 \\
Apartment 3 & -0.065 & -0.30 & 11.2 & -0.012 & -0.055 & 2.11 \\
Apartment 4 & -0.059 & -0.28 & 10.6 & 0.021 & 0.10 & 3.80 \\
Apartment 5 & -0.14 & -0.68 & 25.7 & 0.040 & 0.20 & 7.53 \\
\hline
\end{tabular}

\subsubsection{Room Level}

For the room-level simulations, the apartment with the most detailed time diary was chosen. The apartment was then modeled as four zones: living room (including hall), kitchen, bedroom, and bathroom together with a walk-in closet. The doors inside the apartment were set to never close since this seemed to be the case when visiting the tenant. Table 14 shows the comparison between BES-ref and BES-v.2 in apartment 5 on the second floor. 
Table 14. Comparison of apartment 5, second floor, at the room level between BES-ref and BES-v.2 for the validation period and for a full-year simulation.

\begin{tabular}{|c|c|c|c|c|c|c|}
\hline \multirow{2}{*}{$\begin{array}{c}\text { Apartment 5, Floor } 2 \\
\text { Living room }\end{array}$} & \multicolumn{3}{|c|}{ Simulation Period 19/11-23/11 } & \multicolumn{3}{|c|}{ Full Year Simulation } \\
\hline & BES-ref & BES-v.2 & Difference & BES-ref & BES-v.2 & Difference \\
\hline Energy supplied by water radiators $(\mathrm{DH})(\mathrm{kWh})$ & 2.4 & 15.9 & $563 \%$ & 190.7 & 564.8 & $196 \%$ \\
\hline Energy loss due to airing $(\mathrm{kWh})$ & 1.7 & 2.6 & $53 \%$ & 122 & 242.9 & $99 \%$ \\
\hline Indoor temperature $\left({ }^{\circ} \mathrm{C}\right)$ & $19.6-20.1$ & $19.6-20.2$ & - & 19.4-32.1 & 18.7-30.9 & - \\
\hline Maximum $\mathrm{CO}_{2}(\mathrm{ppm})$ & 579.6 & 846.8 & 267.2 & 597.5 & 883.6 & 286.1 \\
\hline Maximum PPD (\%) & 21.7 & 21.6 & -0.10 & 87.8 & 66.7 & -21.06 \\
\hline \multicolumn{7}{|l|}{ Kitchen } \\
\hline Energy supplied by water radiators $(\mathrm{DH})(\mathrm{kWh})$ & 1.44 & 0 & $-100 \%$ & 100.6 & 0 & $-100 \%$ \\
\hline Energy loss due to airing $(\mathrm{kWh})$ & 0.84 & 0.2 & $-76 \%$ & 61.1 & 45.1 & $-26 \%$ \\
\hline Indoor temperature $\left({ }^{\circ} \mathrm{C}\right)$ & $19.6-20.1$ & 19.6-21.1 & - & 19.4-32.6 & $19.0-32.0$ & - \\
\hline Maximum $\mathrm{CO}_{2}(\mathrm{ppm})$ & 559 & 821.5 & 821.5 & 569.6 & 912.8 & 343.2 \\
\hline Maximum PPD (\%) & N/A & 22.4 & - & N/A & 79.5 & - \\
\hline \multicolumn{7}{|l|}{ Bedroom } \\
\hline Energy supplied by water radiators $(\mathrm{DH})(\mathrm{kWh})$ & 5.41 & 8.7 & $61 \%$ & 215.7 & 265.8 & $23 \%$ \\
\hline Energy loss due to airing $(\mathrm{kWh})$ & 0.81 & 4.5 & $456 \%$ & 59.4 & 172.3 & $190 \%$ \\
\hline Indoor temperature $\left({ }^{\circ} \mathrm{C}\right)$ & $19.5-19.8$ & 18.9-19.9 & - & $19.4-32.2$ & $17.6-31.2$ & - \\
\hline Maximum $\mathrm{CO}_{2}(\mathrm{ppm})$ & 546.8 & 793.1 & 246.3 & 557.4 & 807.6 & 250.2 \\
\hline Maximum PPD (\%) & N/A & 25.7 & - & N/A & 72.7 & - \\
\hline \multicolumn{7}{|l|}{ Bathroom } \\
\hline Energy supplied by water radiators $(\mathrm{DH})(\mathrm{kWh})$ & 0.55 & 0 & $-100 \%$ & 40 & 3.4 & $-92 \%$ \\
\hline Energy loss due to airing $(\mathrm{kWh})$ & 0.55 & 0.1 & $-82 \%$ & 39.9 & 27.1 & $-32 \%$ \\
\hline Indoor temperature $\left({ }^{\circ} \mathrm{C}\right)$ & 20.0-20.5 & 20.1-20.2 & - & 19.7-31.9 & 19.7-30.3 & - \\
\hline Maximum $\mathrm{CO}_{2}(\mathrm{ppm})$ & 579.5 & 834.1 & 254.6 & 596.4 & 881.7 & 285.3 \\
\hline Maximum PPD (\%) & N/A & 18.5 & - & N/A & 60.6 & - \\
\hline \multicolumn{7}{|l|}{ Apartment total } \\
\hline Energy supplied by water radiators $(\mathrm{DH})(\mathrm{kWh})$ & 9.8 & 24.6 & $151 \%$ & 547 & 834 & $52 \%$ \\
\hline AHU heating (electrical) $(\mathrm{kWh})$ & 7.5 & 7.7 & $3 \%$ & 332.6 & 345.3 & $4 \%$ \\
\hline Total energy use for space heating $(\mathrm{kWh})$ & 13.4 & 32.3 & $87 \%$ & 879.6 & 1179.3 & $34 \%$ \\
\hline Energy loss due to airing $(\mathrm{kWh})$ & 3.9 & 7.4 & $90 \%$ & 282.4 & 487.4 & $73 \%$ \\
\hline Indoor temperature $\left({ }^{\circ} \mathrm{C}\right)$ & $19.5-20.5$ & 18.9-21.1 & - & $19.4-32.6$ & $17.6-32.0$ & - \\
\hline Maximum $\mathrm{CO}_{2}(\mathrm{ppm})$ & 579.6 & 846.8 & 267.2 & 597.5 & 912.8 & 315.3 \\
\hline Maximum PPD (\%) & 21.7 & 25.7 & 4.02 & 87.8 & 79.5 & -8.32 \\
\hline
\end{tabular}


When comparing the models at the room level, there can also be seen large differences between the results. The living room is the room where the most difference can be seen in energy supplied by the radiators. Even though it does not have the highest losses due to airing, it does seem to use a lot of energy trying to heat up the other rooms in the apartment. This, in combination with airing through the balcony door (which in this apartment is very frequent, and the door is situated in the living room), and the fact that the occupant in BES-ref is only active in the living room, contributing to higher internal gains in that model, should be the most probable cause of this. In the kitchen, no energy is supplied by the water radiators during simulations for the validation period. This is because the tenant spends quite a lot of time in the kitchen, as well as using the stove and other household appliances there, which is all in the detailed schedules in BES-v.2, which results in all energy coming from internal gains. The bedroom is the room where the most airing losses occur in BES-v.2, which is probably due to the fact that the tenant sometimes has the window open during the nights.

\subsection{General Discussion}

La Fleur, Moshfegh, and Rohdin [21] concluded that assumptions on user behavior have a significant impact on energy-saving potential when renovating or retrofitting a building, and this study shows how much difference there can actually be due to assumptions of user behavior. The largest differences in energy use in this study between using standardized user input data and behavioral schedules based on data collected from the actual building were due to airing and electricity use. It seems as though the standardized user input data are a bit too generalized and cannot actually be used in this case where the studied object is a retirement home. Even so, when designing a building for elderly care, one is supposed to use template values for regular housing in the calculations and/or simulations, as was done in BES-ref. The results show that schedules created from using time diaries and logged measurements bring the simulated results much closer to reality than just using template values. There was, however, quite a difference between the level of detail in the time diaries. The time diary shown in this article was the most detailed one, but some of the tenants almost only wrote whether they were home or not, and some of them wrote activities with no time. It is, therefore, of great importance, when conducting a study with time diaries, that the participants are told what sort of activities they should write down and to make sure they understand the importance of the level of detail in their time diaries. Since logged measurements could only be done in two apartments at the same time in this study due to a lack of equipment, it means that the schedules for the apartments were validated during different weeks, and only for one week during the heating season. In future studies, one should try to use time diaries and logged measurements at least four times during a year, if the building is situated in the temperate climate zone, i.e., one week in each season of the year (winter, spring, summer, and autumn), to see if there are any changes in the user behavior and to be able to make even more detailed schedules which vary during full-year simulations. Since this is a case study, conducted on a single retirement home, it might be hard to generalize the findings of this study to all retirement homes. However, the authors believe that most of the behavioral patterns are probably quite similar in homes of elderly people and retirement homes in Sweden. More studies on this type of housing are, however, required to be able to generalize and to create template values for retirement homes or housing for elderly people. One thing that also needs to be accounted for is that people that are over 70 today might behave a lot differently from people that will turn 70, for example, in 30 years, since they probably will have other accustomed behaviors. It should also be pointed out that user behavior is not the only thing that can affect the energy performance gap; the building parameters themselves such as U-values, air flow in the ventilation system, temperature set-point, etc. are of great importance to have a model that can predict energy use well. In this study, however, the main focus was on user behavior and the difference in energy use when using standardized user input data compared to using schedules based on gathered data from the actual building. The building parameters that were measured were indoor temperature to determine temperature set-point, leakage through the building envelope with blower door technology, ventilation air flow, and temperature, while U-values 
for the walls and windows were not measured. The U-values are based on construction blueprints and product specifications of the used materials. This can of course affect how the different user input data affect the simulated energy use and could, therefore, give either higher or lower discrepancies between the two cases (BES-ref and BES-v.2).

\section{Conclusions}

Time diaries and interviews, together with logged measurements, can be great tools to detect behavior that affects energy use in buildings; as far as the authors are concerned, this was not done simultaneously before. The time diaries provide a way of determining what actually causes variations in logged measurements. This can greatly benefit researchers studying user behavior and energy use in buildings and/or people that work with BES models. The reason is that it eliminates a lot of assumptions about the user behavior and/or why variations occur in measurements. This can also be good when deciding on which measures should be taken if the building is being retrofitted, since it gives a clear view on how the building is being used. They can also be used to create detailed schedules and behavioral models for BES models so that they are better at predicting actual energy use. However, using and creating these schedules from scratch is time-consuming and costly, which means that this method would probably not be viable in industry. Because of this, we believe that standardized user input data are still necessary, but there needs to be more variety in these standards. As shown in this article, user data for regular residential housing did not work well when used in this particular retirement home. Therefore, we believe that more studies of this nature need to be done on these sorts of buildings and also different kinds of buildings, both public and domestic. Thus, when designing new buildings or planning to renovate or retrofit old ones, there will be standardized user input data for that exact type of building. The largest offsets between using standardized user input data and input data from actual logged measurements and time diaries in this case could be seen in energy losses due to airing, and the amount of household electricity use. The tenants in this study aired a lot more and used a lot less electricity than the general population living in residential houses, according to Reference [10], which affected the energy use quite substantially. Based on the present findings, an update to the source hierarchy is also suggested for input data to BES models described by Raftery et al. [4]. Since time diaries represent a sort of in situ measurement (but not technical, since it is also behavioral), it should be in second place in the source hierarchy created by Raftery et al. [4], together with spot and short-term measurements. With time diaries, short-term measurements can be greatly expanded, since one can actually determine why drops and peaks occur in the different measurements. This would create the following source hierarchy: data-logged measurements, spot or short-term measurements and time diaries, direct observation, operator and personnel interviews, operation documents, commissioning documents, benchmark studies and best practice guides, standards, specifications, and guidelines, and design stage information.

Author Contributions: Conceptualization, J.C. and B.M.; data curation, J.C.; funding acquisition, B.M.; investigation, J.C. and K.T.; methodology, J.C.; project administration, B.M.; supervision, B.M.; writing-original draft, J.C. and K.T.

Funding: This work was funded by the KK foundation (KK-stiftelsen, Stiftelsen för Kunskaps och Kompetensutveckling), grant number 20150133, and the Swedish Energy Agency (Energimyndigheten), grant number 37492-1.

Acknowledgments: The authors of this article would like to thank Jakob Rosenquist, previously employed at Linköping University's department of energy system, for the great help while conducting measurements at the studied site. We would also like to thank Patrik Rohdin for helping with the IDA-ICE simulations and for initiating the project together with Kajsa Ellegård at Linköping University, Sweden. Also, huge thanks goes out to all the residents and staff at Räknestickan Retirement Home for their participation in the study and for letting us into their homes and their workplace to do our measurements.

Conflicts of Interest: The authors declare no conflicts of interest. 


\section{References}

1. European Commission Buildings. Available online: https://ec.europa.eu/energy/en/topics/energy-efficiency/ energy-performance-of-buildings (accessed on 29 May 2019).

2. Gynther, L.; Lappillone, B.; Pollier, K. Energy Efficiency Trends and Policies in the Household and Tertiary Sectors. An Analysis Based on the ODYSSEE and MURE Databases. Available online: http://www.odysseemure.eu/publications/br/energy-efficiency-trends-policies-buildings.pdf (accessed on 29 May 2019).

3. Energimyndigheten flerbostadshus och lokaler 2016; Energimyndigheten: Eskilstuna, Sweden, 2016.

4. Raftery, P.; Keane, M.; O’Donnell, J. Calibrating whole building energy models: An evidence-based methodology. Energy Build. 2011, 43, 2356-2364. [CrossRef]

5. van den Brom, P.; Meijer, A.; Visscher, H. Performance gaps in energy consumption: household groups and building characteristics. Build. Res. Inf. 2017, 46,1-17. [CrossRef]

6. Clarke, J.A.; Joe, A. Energy Simulation in Building Design; Butterworth-Heinemann: Oxford, UK, 2001; ISBN 9780750650823.

7. Andersen, R.V.; Olesen, B.W.; Toftum, J. Simulation of the Effects of Occupant Behaviour on Indoor Climate and Energy Consumption. In Proceedings of the Clima 2007: 9th REHVA world congress: WellBeing Indoors, Helsinki, Finland, 10-14 June 2007.

8. Svebyprogrammet. Brukarindata Undervisningsbyggnader; Sveby: Stockholm, Sweden, 2016.

9. Sveby. Brukarindata Kontor: Version 1.1; Sveby: Stockholm, Sweden, 2013.

10. Sveby. Brukarindata Bostäder; Sveby: Stockholm, Sweden, 2012.

11. Delzendeh, E.; Wu, S.; Lee, A.; Zhou, Y. The impact of occupants' behaviours on building energy analysis: A research review. Renew. Sustain. Energy Rev. 2017, 80, 1061-1071. [CrossRef]

12. Richardson, I.; Thomson, M.; Infield, D. A high-resolution domestic building occupancy model for energy demand simulations. Energy Build. 2008, 40, 1560-1566. [CrossRef]

13. Widén, J.; Lundh, M.; Vassileva, I.; Dahlquist, E.; Ellegård, K.; Wäckelgård, E. Constructing load profiles for household electricity and hot water from time-use data-Modelling approach and validation. Energy Build. 2009, 41, 753-768. [CrossRef]

14. Chiou, Y.-S.; Carley, K.M.; Davidson, C.I.; Johnson, M.P. A high spatial resolution residential energy model based on American Time Use Survey data and the bootstrap sampling method. Energy Build. 2011, 43, 3528-3538. [CrossRef]

15. Aerts, D.; Minnen, J.; Glorieux, I.; Wouters, I.; Descamps, F. A method for the identification and modelling of realistic domestic occupancy sequences for building energy demand simulations and peer comparison. Build. Environ. 2014, 75, 67-78. [CrossRef]

16. Sahlin, P.; Eriksson, L.; Grozman, P.; Johnsson, H.; Shapovalov, A.; Vuolle, M. Whole-building simulation with symbolic DAE equations and general purpose solvers. Build. Environ. 2004, 39, 949-958. [CrossRef]

17. Kropf, S.; Zweifel, G. Validation of the Building Simulation Program IDA-ICE According to CEN 13791 "Thermal Performance of Buildings - Calculation of Internal Temperatures of a Room in Summer Without Mechanical Cooling-General Criteria and Validation Procedures"; Fachhochschule Zentralschweiz: Luzern, Schweiz, 2001.

18. Achermann, M. Validation of IDA ICE, Version 2.11.06 With IEA Task 12-Envelope BESTEST; Fachhochschule Zentralschweiz: Luzern, Schweiz, 2000.

19. Ryan, E.M.; Sanquist, T.F. Validation of building energy modeling tools under idealized and realistic conditions. Energy Build. 2012, 47, 375-382. [CrossRef]

20. Coakley, D.; Raftery, P.; Keane, M. A review of methods to match building energy simulation models to measured data. Renew. Sustain. Energy Rev. 2014, 37, 123-141. [CrossRef]

21. La Fleur, L.; Moshfegh, B.; Rohdin, P. Measured and predicted energy use and indoor climate before and after a major renovation of an apartment building in Sweden. Energy Build. 2017, 146, 98-110. [CrossRef]

22. Liu, L.; Rohdin, P.; Moshfegh, B. Evaluating indoor environment of a retrofitted multi-family building with improved energy performance in Sweden. Energy Build. 2015, 102, 32-44. [CrossRef]

23. Molin, A.; Rohdin, P.; Moshfegh, B. Investigation of energy performance of newly built low-energy buildings in Sweden. Energy Build. 2011, 43, 2822-2831. [CrossRef]

24. Rohdin, P.; Molin, A.; Moshfegh, B. Experiences from nine passive houses in Sweden-Indoor thermal environment and energy use. Build. Environ. 2014, 71, 176-185. [CrossRef] 
25. Gauthier, S.; Shipworth, D. Behavioural responses to cold thermal discomfort. Build. Res. Inf. 2015, 43, 355-370. [CrossRef]

26. Andersen, R.V.; Toftum, J.; Olesen, B.W. Simulation of the effects of window opening and heating set-point behaviour on indoor climate and building energy performance. In Proceedings of the Healthy Buildings 2009, Syracuse, NY, USA, 13-17 September 2009.

27. Isaksson, C.; Ellegård, K. Anchoring energy efficiency information in households' everyday projects: Peoples' understanding of renewable heating systems. In Energy Efficiency; Springer: Berlin/Heidelberg, Germany, 2015; pp. 353-364.

28. Ellegård, K.; Palm, J. Visualizing energy consumption activities as a tool for making everyday life more sustainable. Appl. Energy 2011, 88, 1920-1926. [CrossRef]

29. Hellgren, M. Energy Use as a Consequence of Everyday Life; Linköping University: Linköping, Sweden, 2015; ISBN 9789176859100.

30. Clifford, N.; Cope, M.; Gillespie, T.; French, S. Key Methods in Geography, 3rd ed.; Sage Publications: Thousand Oaks, CA, USA, 2016; ISBN 9781446298602.

31. Vrotsou, K.; Bergqvist, M.; Cooper, M. PODD: A Portable Diary Data Collection System. In Proceedings of the 2014 International Working Conference on Advanced Visual Interfaces, Como, Italy, 27-29 May 2014; pp. 381-382.

32. SCB. Statistikdatabas för Äldreomsorg. Available online: https://www.socialstyrelsen.se/statistik/ statistikdatabas/aldreomsorg (accessed on 16 May 2019).

33. United Nations, UN. Transforming our World: The 2030 Agenda for Sustainable Development; United Nations: New York, NY, USA, 2015.

34. Abramsson, M.; Andersson, E.V.A. Changing preferences with ageing-housing choices and housing plans of older people. Hous. Theory Soc. 2016, 33, 217-241. [CrossRef]

35. Abramsson, M.; Andersson, E.V.A.K. Residential mobility patterns of elderly-leaving the house for an apartment. Hous. Stud. 2012, 27, 582-604. [CrossRef]

36. Sveby. Brukarindata för energiberäkningar i bostäder; Sveby: Stockholm, Sweden, 2009.

37. Carlander, J.; Tullsson, F. Utredning av energi och inomhusklimat samt åtgärdsförslag för kvarteret Räknestickan 1; Linköping University: Linköping, Sweden, 2014.

38. Ruiz, G.R.; Bandera, C.F. Validation of calibrated energy models: Common errors. Energies 2017, $10,1587$. [CrossRef]

39. ASHRAE. Guideline 14-2002: Measurement of Energy and Demand Savings; ASHRAE: Atlanta, GA, USA, 2002. 